\title{
Quinazoline pharmacophore in therapeutic medicine
}

\author{
Olayinka Oyewale Ajani' ${ }^{1}$, Damilola Victoria Aderohunmu' ${ }^{1}$, Ejike Nzube Umeokoro' and \\ Ayodele Ojo Olomieja ${ }^{2}$
}

${ }^{1}$ Department of Chemistry, Covenant University, CST, Canaanland, Km 10 Idiroko Road, P.M.B. 1023, Ota, Ogun State, Nigeria; ${ }^{2}$ Department of Chemistry, Ogun State Institute of Technology, Igbesa, Ogun State, Nigeria.

\begin{tabular}{|c|c|}
\hline Article Info & \\
\hline Received: & 16 November 2015 \\
\hline Accepted: & 16 July 2016 \\
\hline Available Online: & 15 August 2016 \\
\hline DOI: $10.3329 /$ bjp. & v11i3.25731 \\
\hline $\begin{array}{l}\text { Cite this article: } \\
\text { Ajani OO, Adero } \\
\text { koro EN, Olomie } \\
\text { pharmacophore } \\
\text { cine. Bangladesh } \\
\text { 11: 716-33. }\end{array}$ & $\begin{array}{l}\text { hunmu DV, Umeo- } \\
\text { ja AO. Quinazoline } \\
\text { therapeutic medi- } \\
\text { J Pharmacol. 2016; }\end{array}$ \\
\hline
\end{tabular}

\begin{abstract}
This present study comprehensively expatiates the functionalized utilization of quinazoline scaffolds in drug development and furnishes latest updates in pharmacological appositeness of its derivatives in order to reveal novel pathways for therapeutic targets. It traverses numerous biological potentials of quinazoline in the contemporary time to allow researchers' unhindered access to the beneficial role of quinazoline in fighting infectious diseases for future drug discovery. This work provides broad overview of medicinal survey of quinazoline chemistry valuable in the discovery of more efficient clinical trials and to summarize the most promising molecular targets for drug design.
\end{abstract}

\section{Introduction}

Over the years, heterocyclic chemistry has gained tremendous attention because of its unavoidable pharmacological diversity in medicinal chemistry research. There has been considerable attention on the preparation of useful heterocyclic compounds in organic synthesis (Ajani and Nwinyi, 2009). These structures can either be aromatic or non-aromatic rings (Joule and Mills, 2000). Pyrimidine falls under the common azines 6-membered aromatic nitrogen heterocycles (Eicher and Hauptmann, 2003), while quinazoline falls under the category of benzo-fused azines because it resulted from the fusion of a benzene ring and a pyrimidine atom (Asif, 2014). Heterocyclic frameworks constitute most of the active ingredients and building blocks of many pharmaceuticals, agrochemicals and veterinary products (Ouahrouch et al., 2014; Murgan et al., 2003).

In comparison with our earlier review, quinazoline is an heterocycle which belongs to benzodiazine family with its heteroatomic nitrogen located at 1- and 3positions (Ajani, 2014). Evolution of quinazolines began only with discovery of febrifugine, a 'quinazolinone alkaloid", which was isolated from the Chinese plant
Aseru (Dichroa febrifuga Lour) and was reported to possessing antimalarial potential. It was first synthesized by Gabrial in the year 1903 and was first isolated from the Chinese plant aseru (Selvam and Kumar, 2011).

Quinazoline is the most commonly experienced heterocyclic core in medicinal research, owing to its wide spectrum of pharmacological potential (Luo et al., 2014; Selvam et al., 2008) and a huge amount of its derivatives are referred to be salient structural synthons of numerous physiological relevance and pharmaceutical applications (Luo et al., 2014). These include usage in drug design and medicinal researches because they have been reported to display anti-tobacco mosaic virus (anti-TMV), anti-HIV, anti-cancer, antimicrobial, antifungal (Patel and Patel, 2011), anti-inflammatory (Kumar et al., 2010), anti-hypertensive, antimalarial (Werbel and Degnan, 1987) and anti-convulsant (Aly et al., 2010) activities among others.

Furthermore, quinazoline and quinazolinone compounds are also used in the preparation of various functional materials for synthetic chemistry and also present in various drugs molecule (Rajput and Mishra, 
2012). Novel quinazoline-urea analogues were recently reported as modulators for $A \beta$-induced mitochondrial dysfunction making them valuable template in the treatment of various neurodegenerative disorders (Elkamhawy et al., 2014). Sulfonamides containing quinazoline core structure was reported to be suitable toolbox for better comprehension of the usefulness of bacterial carbonic anhydrases in pathogenesis (Alafeefy et al., 2014). Quinazolinyloxybiaryl urea was identified as a new class of inhibitor against SUMO activating enzyme 1 which is an excellent oncology target (Kumar et al., 2013). Quinazoline core was not left out in the new advancement in phenoclustering of diverse model systems as an option for the recognition of targeted site in drug development (Williams and Hong, 2013). Linear and angular $4^{\prime}, 5^{\prime}$-dimethylfuroquinazolines proved to intercalate within the DNA double helix, however they could not photo-bind DNA bases in the presence of ultraviolet radiation (Miolo et al., 2014). Fluorescence relays increased sequential identification of $\mathrm{Cu}^{2+}$ and $\mathrm{CN}^{-}$through effect of novel quinazoline scaffold (Liu et al., 2013; Tang et al., 2013) and their role as turn on fluorescence for cysteine and chemodosimeter for $\mathrm{NO}$ has also been reported (Anand et al., 2014). Some quinazoline motifs were shown to display bronchodilatory effect at low micromolar concentrations on isolated rat trachea, and low toxicity both on Balb/c 3T3 mouse fibroblast cells and in mice (Špulák et al., 2014). Some valuable quinazoline-based compounds include antitumor erlotinib 1, anti-cancer iressa $\mathbf{2}$ and kinase inhibitor lapatinib $\mathbf{3}$ (Sharma et al., 2013a; Garofalo et al., 2011) as presented in Figure 1.

\section{Physical properties}

Quinazoline is a nitrogen-based heterocyclic entity which contains a fusion of benzene structure on a pyrimidine heterocycle. Hence, it qualifies to be called benzopyrimidine. It is a yellow colored solid compound having the chemical formular $\mathrm{C}_{8} \mathrm{H}_{6} \mathrm{~N}_{2}$ and a molecular mass of $130.1 \mathrm{~g} / \mathrm{mol}$. It is usually found in crystalline state and it is isomeric with other naphthyridines including quinoxaline, phthalazine and cinnoline (Selvam et al., 2008).

\section{Natural occurrence}

Quinazoline occurs mostly as alkaloid in root and leaves of some medicinal plants such as Dichroa febrifuga (also called Chinese quinine) which belongs to the Saxifragaceae family (McLaughlin et al., 2014). They are present there as isomeric alkaloids $(+)$-febrifugine $4 \mathbf{a}$ and (+)-isofebrifugine $\mathbf{4 b}$. The recent review summarized historical isolation information and the chemistry studies which culminated in the correct structural elucidation of this naturally occurring quinazoline-based alkaloid called febrifugine and its isomer, isofebrifugine (McLaughlin et al., 2014). Hydrachine A 5, a natural quinazoline-core, was isolated from the roots of Hydrangea chinensis (Chang et al., 2003). The structures of these naturally occurring quinazoline motifs are as shown in Figure 2.

\section{Structure of quinazoline/auinazolinone}

In quinazoline structure, the reactivity behaviour of heteroatomic six-membered ring is significantly affected by the incorporated benzene nucleus. The two $N$ heteroatoms are slightly different in their reaction, and the existed polarization of the $\Pi$ bond at 3,4-position is unveiled in the marked reactions of quinazoline. The substituted quinazolines nature is mainly determined by position of substituents attachment, i.e. if they are either attached to the heteroatomic ring portion or benzene nucleus. Another factor has to do with whether there is complete conjugation in the pyrimidine ring or not (Vijayakumar et al., 2013).
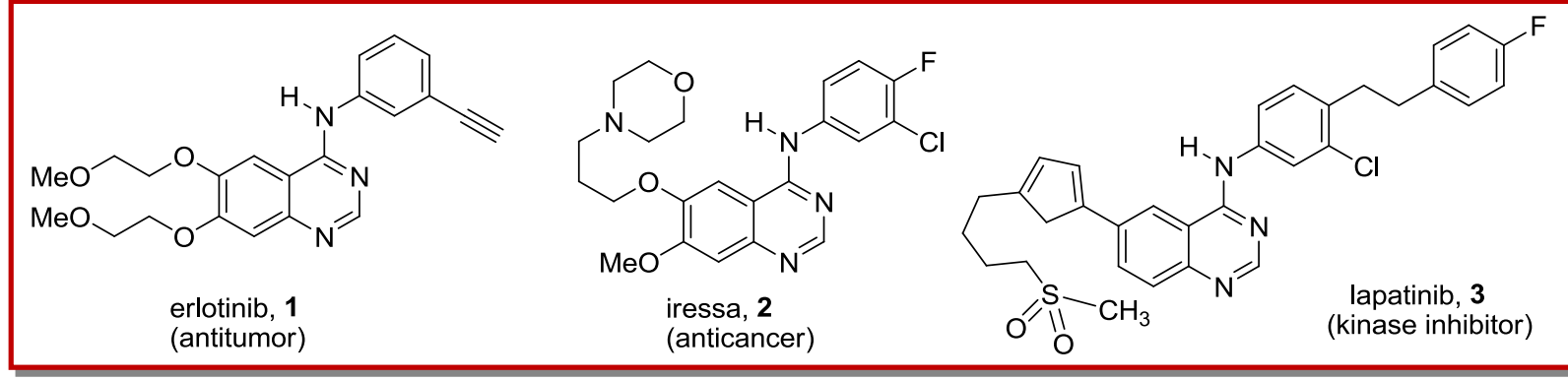

Figure 1: Selected commercially available drug bearing quinazoline core<smiles>O=C(C[C@@H]1NCCC[C@H]1O)Cn1cnc2ccccc2c1=O</smiles><smiles>O=c1c2ccccc2ncn1C[C@]1(O)C[C@@H]2NCCC[C@H]2O1</smiles><smiles>O=C1C[C@@H]2[C@@H](O)CCCN2[C@H](n2cnc3ccccc3c2=O)C1</smiles>

Figure 2: Structural identity of some naturally occurring quinazoline motifs 


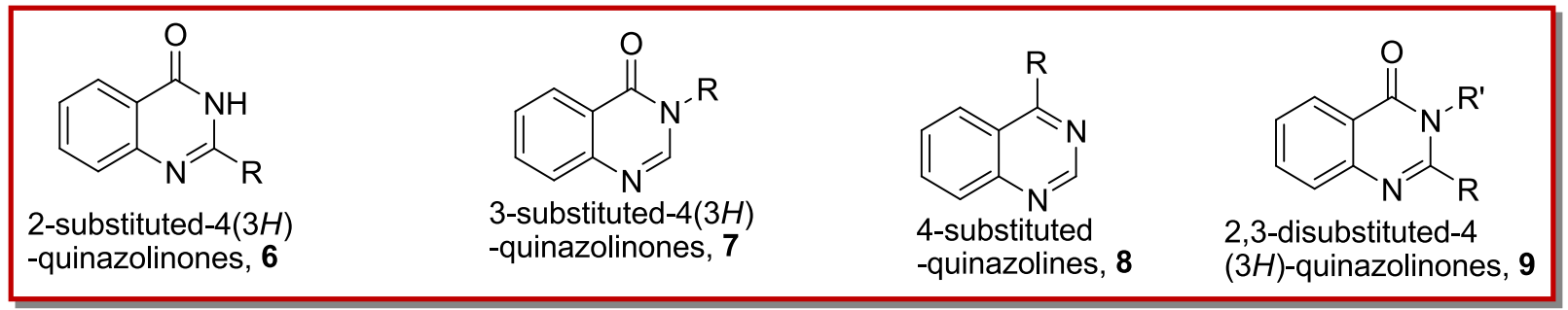

Figure 3: Classification of quinazoline and quinazolinone derivatives

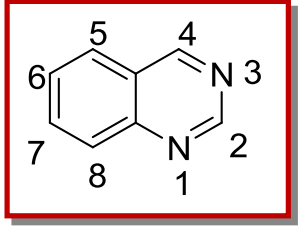

\section{Classification of quinazolinones}

Based on substitution pattern of its ring system, quinazolinones can be classified into the following categories: 2-substituted-4(3H)-quinazolinones 6, 3substituted one 7, 4-substituted one 8 and 2,3-disubstituted type 9 (Mhaske and Argade, 2006) as shown in Figure 3. Based on the location of oxo group, quinazoline could be further categorized into three other classes which include: Quinazolin-2(1H)-ones, quinazolin-4(3H)-ones and quinazoline-2,4 $(1 H, 3 H)$ dione (Mahato et al., 2011). It is worthy to note that, of all the templates, quinazolin- $4(3 H)$-ones are the commonest privileged in terms of naturally occurring molecular features or intermediates in numerous reported construction route in biosyn-thesis (Mahato et al., 2011).

\section{Justification for expository study on quinazoline derivatives}

The recent development in the medicinal importance of quinazoline derivatives has necessitated strong international effort for the development of new and better synthetic strategies for their preparations. The relinquishable attribute of its characteristic offers an effective justification for the discovery of these techniques (Portela-Cubillo et al., 2009). Synthetic chemists are continuously engaging the preparation of quinazoline and its derivatives by simple and effective methods because of its diverse biological applications such as anti-cancer, antiviral and antitubercular agents. The quinazoline unit is represented in a number of useful natural product scaffolds with laudable activities against numerous pharmacological disorders. On this note, quinazoline moieties are one of the strongest ever reported inhibitors cellular phosphorylation and tyrosine kinase. These heterocycles have functioned as common ligands in deoxyribonucleic acid, which link to adenosine receptors, as well as being efficacious as tough antibacterial agents (Portela-Cubillo et al., 2009).
No wonder their frameworks serve as the foundation in the application that have to do with lots of pharmaceutical, agrochemical, and veterinary products (Portela-Cubillo et al., 2009). The increasing significance of quinazolines around therapeutic research has been noticed based on the reported highly voluminous selling of the quinazoline-based drugs called erlotinib 1, which serves a well-recognized curing agent for various kinds of tumours (Fung and Grandis, 2010; PortelaCubillo et al., 2009) and prazosin, which serves as a blocking agent for R-adrenergic blocker. In the same vein, iressa 2, which serves as an inhibitor of EGFR, has been certified by the United State Food and Drug Administration for the treatment of lung cancer (Portela -Cubillo et al., 2009). Prozosin, which is another radrenergic blocker, is a popular drug bearing the quinazoline unit. Quinazolin-4(3H)-one bearing a benzyl functionality at 2-position has been reported to have selective inhibitory efficiency on human leucocyte elastase as well as on serine protease while 1,3-dimethyl -1 H-quinazoline-2,4-dione did not only act against inflammation but also showed strong and encouraging analgesic as well as anticonvulsant potentials (Connolly et al., 2005; Maskey et al., 2004). 4(3H)-Quinazoline derivatives possess a broad spectrum of biological activities and have been identified as antidiabetic and CNS depressants (Ding et al., 2004). Due to the existence of microorganisms' resistance phenomenon to drugs currently available in the market and consistent increase in the outbreak of new diseases, it is highly imperative and necessary to continuously design and prepare novel heterocyclic scaffolds which display improved druggability relevance for medicinal research (Ajani, 2014). Therefore, the main goal of this review herein is to harness the valuable updated information in the medicinal applications and pharmacological expertise of quinazoline motifs so as to unfold novel routes toward active targets in drug development.

\section{Synthetic methods}

Quinazoline is relatively easy to prepare and many derivatives have been synthesized in order to obtain biologically active motifs. Medicinal chemistry researchers have designed series of quinazoline templates having diverse bioactivities by incorporating and attaching several active functionalities to the quinazoline core with the aid of improved synthetic 
methodologies (Wang and Gao, 2013). In an earlier review, the representative synthetic methods for quinazoline moieties, either traditional or novel were summarized, and they were classified into five main categories which include: Aza-reaction, microwaveassisted reaction, metal-catalyzed reaction, ultrasoundpromoted reaction and phase-transfer catalysis (Wang and Gao, 2013). First quinazoline compound, 2-cyano3,4-dihydro-4-oxoquinazoline (Maheswari et al., 2010), was prepared in 1869 through the reaction of cyanogens with anthranilic acid and later documented by Armarego in 1967.

\section{Biological importance of quinazoline}

Quinazoline and its quinazolinone skeletons are recurrently encountered heterocyclic compounds in therapeutic medicine's literature with wide range of utilization including antidiabetic, antileishmanial, antihypertensive, CNS depressant, anticonvulsant, antitubercular, anti-HIV, antibacterial, anti-cancer activities among others.

\section{Anti-cancer activity}

Cancer has continued to be topic of great attention in all regions of the world due to its global health challenge issue to be a leading health problem in developed as well as developing countries. It has been consistently associated with high mortality rate due to various worldwide factors (Antonello et al., 2006). Cancer is an abnormal cell growth which is identify through a shift in the controlled mechanisms which guides cell proliferation and differentiation (Al-Omary et al., 2012). Quinazoline bearing sulfonamide functionalities were recently recognized as categories of cancer chemotherapeutics which exhibited noticeable therapeutic potentials on solid tumours (Mohamed et al., 2015). 4Anilinoquinazoline bearing sulfonamide at 6-position was reported to inhibit the breast cancer cell line growth at as low as $\mathrm{IC}_{50}=5.5 \mu \mathrm{M}$ based on the result of investigation of the screening carried out by Yassen et al. (2014) whereas when the sulfonamide was on para position of the aniline ring there was a reduction in anti -cancer activity to $\mathrm{IC}_{50}=77.9 \mu \mathrm{M}$ (Ghorab et al., 2016). Quinazolinedione-based redox modulators, 6-((3-acetylphenyl)amino)quinazoline-5,8-dione, was discovered as therapy for pancreatic cancer since the oxidative stress enhanced through it, catalyzed activation of stress kinases (p38/JNK) thereby leading to cancer cell death (Pathania et al., 2014).

\section{EGFR inhibitory activity}

Comprehensive clinical studies showed that inhibiting EGFR family receptor TKs represent a major advance in the treatment of solid tumor. Gefitinib and erlotinib are quinazoline-based compounds which happened to be earlier reported salient EGFR inhibitor authorized for the curing of diseases related to NSCLC (Wang et al.,
2016). Their mechanism of action was through competitive binding to adenosine triphosphate (ATP)-binding pocket of the intracellular EGFR TK site according to docking study report; hence, effectively block the aberrant EGFR down-stream signaling required during tumor survival as well as its proliferation (Wang et al., 2016; Hynes and Lane, 2005). Owing to this ability, structural modifications of earlier discovered gefitinib and erlotinib have been achieved to produce more effective EGFR inhibitors. For instance, EGFR was reported clinically authenticated during rational drug design as targeted entity for cancer chemotherapy. In addition, various small molecular inhibitors have been designed and made available to members of public (Zhang et al., 2013a) as quinazoline-based reversible inhibitor, e.g. icotinib (Tan et al., 2012) and irreversible inhibitors namely; afatinib (Minkovsky and Berezov, 2008), canertinib and newly reported afatinib derivative (Zhang et al., 2013a). According to results of the molecular docking study showed in Figure 4, the comparison between the binding modes of the 6,7dimethoxy-derivative of quinazoline (LASSBio-1814; $\mathrm{IC}_{50}=2.4 \mu \mathrm{M}$ for EGFRwt and $1.02 \mu \mathrm{M}$ for VEGFR-2) and the 6,7-methylenedioxy-derivative of quinazoline (LASSBio-1815; $\mathrm{IC}_{50}=34.6 \mu \mathrm{M}$ for EGFRwt and $26.9 \mu \mathrm{M}$ for VEGFR-2) demonstrated that the structural modification performed led to the loss of important hydrophobic interaction with Val726, Leu718 and Leu792 amino acid residues in EGFRwt binding site; and with Val848, Leu840 and Phe918 amino acid residues in VEGFR-2 binding site (Barbosa et al., 2014).

\section{Anti-proliferative activity}

Over the years, it has been established that antiproliferative and cyctotoxic drug serve vital functions in oncology drug design, either being used in isolation or in conjunction with other remedial medical procedures which include surgery, radiation and pharmacotherapy (Arya et al., 2014; Jabir et al., 2012). Arya et al. (2014) reported that novel fluorinated benzothiazolo[2,3-b] quinazoline they synthesized via greener approach possessed highly promising photoanti-proliferative activity upon human keratinocytes cell line (Arya et al., 2014) and carcinoma cell line such as HL-60 as well as LoVo cell lines (Arya et al., 2014). Novel array of isatin-based quinazolines have been reported to displayed distinctive selective growth inhibitory effect $\left(\mathrm{IC}_{50}=1.0 \pm 0.2\right.$ to $\left.2.4 \pm 0.4 \mu \mathrm{M}\right)$ by making use of molecular hybridization technique (Fares et al., 2015).

\section{Anti-tubercular activity}

Tuberculosis (TB) is noted to be one of the oldest and most-pervasive diseases in history of mankind (Ankita et al., 2014; Yves, 2007). It has been projected that close to 1000 million of world population will be newly infected, above 150 million individuals will develop 


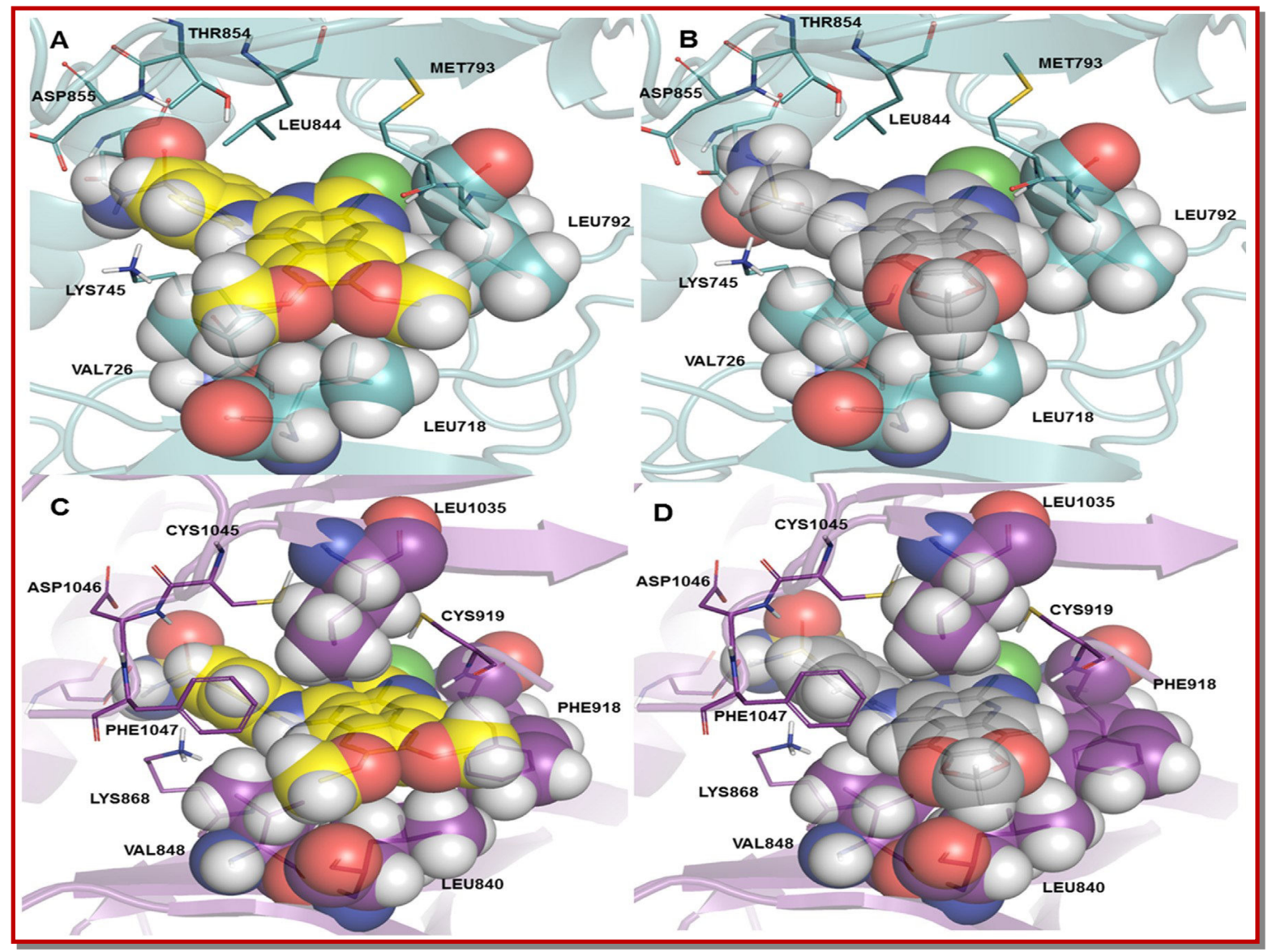

Figure 4: (A) Binding interactions of 6,7-dimethoxy-derivative of quinazoline (yellow) with EGFRwt. (B) Binding interactions of methylenedioxy-derivative of quinazoline (gray) with EGFRwt. (C) Binding interactions of 6,7-dimethoxy-derivative of quinazoline (yellow) with VEGFR-2. (D) Binding interactions of methylenedioxy-derivative of quinazoline (gray) with VEGFR-2. Docking studies were performed with the GOLD 5.1 program. Apolar hydrogen atoms were omitted to improve clarity. The images were generated with PyMol Software (Barbosa et al., 2014)

diseases and 36 million will die of TB, between 2002 and 2020, if adequate preventive and proper control measures are not in place (Ankita et al., 2014; Corbett et al., 2003). Due to the difficulty in the treatment of drug resistant forms of Mycobacterium tuberculosis, the development of novel antituberculosis drug entities which exhibit new mechanisms of action is urgently demanded with the aim of designing more potent combination therapy (Mathew et al., 2013). An array of new 2-trichloromethyl quinazoline moieties containing substituted secondary amine side chain at $4^{\text {th }}$ position were designed and investigated via in vitro screening for anti-tubercular potential upon M. tuberculosis H37Rv ATCC (Srivastav and Shantakumar, 2013) using Alamar Blue assay. 8-Methoxy-4-[4-[2-(1-piperidyl)ethoxy] phenyl]-5,6-dihydrobenzo[h]quinazolin-2-amine exhibited significant anti-tubercular activity at MIC values $50 \mu \mathrm{M}$ and the in vitro cytotoxicity data using THP-1 cells indicated that it was safe as its MIC value was much lower than the cytotoxic value as documented by Maurya et al. (2013).

\section{Anti-inflammatory activity}

For the past few decades now, a probable conjunction between the application of non-steroidal antiinflammatory agents (NSAIDs) and modified cases of cancer has continued to exist as special topic that needs intense evaluation and research (Chandrika et al., 2008). Using NOS-II as biomarker indicator, generally, quinazoline motifs are well-known to exhibit significant anti-inflammatory properties as inhibitors of NOSII (Farag et al., 2013; Tinker et al., 2003), NFKB, TNF-a (Serya et al., 2015), IMPDH-II (Rajput and Mishra, 2012), MAPK, IL-6, PDE-3 and PDE-4 (Serya et al., 2015). A series of novel $8 / 10$ trifluoromethylsubstituted-imidazo[1,2-c] quinazolines were synthesized and investigated in vivo (rat paw edema) for their anti-inflammatory activity and in silico (docking studies) to recognize the hypothetical binding motif (Rajput and Mishra, 2012; Kumar et al., 2003) with the Cycloxygenase enzymes (COX-1 and COX-2) employing GOLD (CCDC, 4.0.1 version) software and found that compounds (Rajput and Mishra, 2012) 


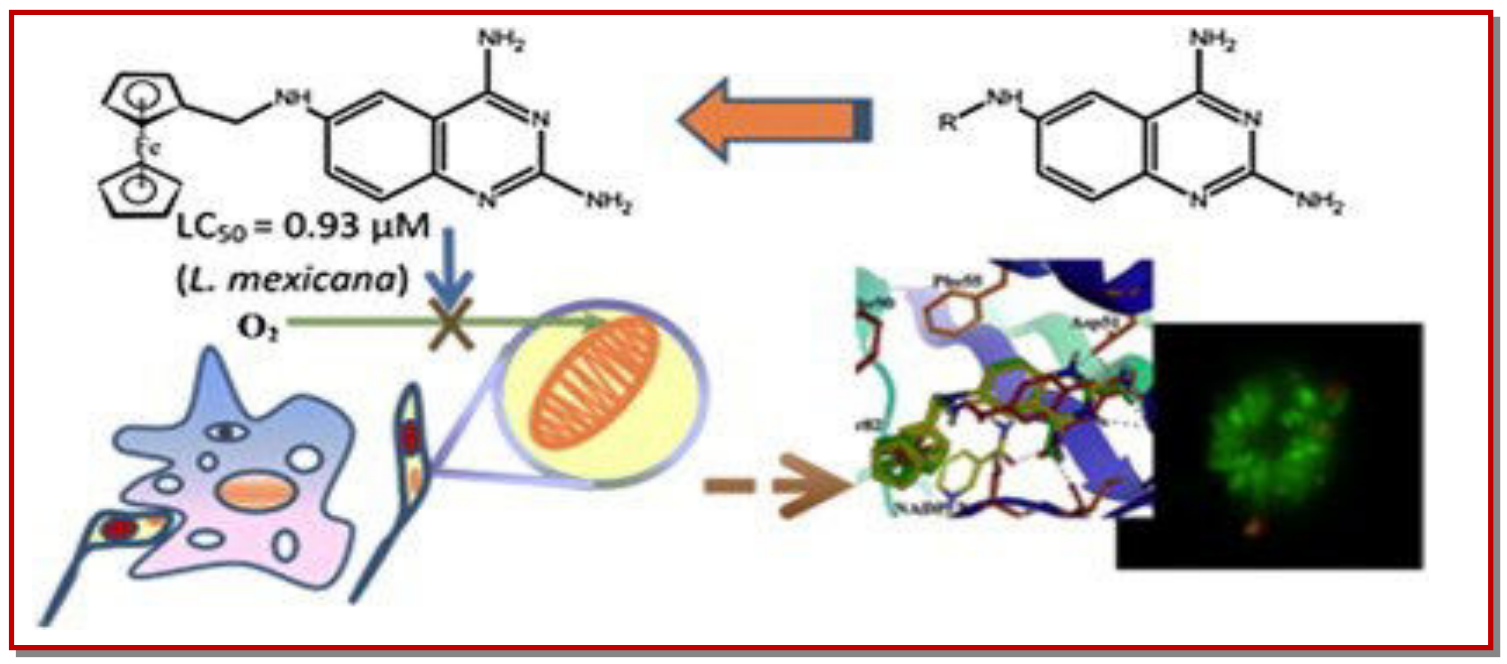

Figure 5: Molecular docking study $N^{6}$-(ferrocenmethyl)quinazolin-2,4,6-triamine as anti-leishmanial agent

showed good anti-inflammatory activity against standard, indomethacin. Quinazoline derivatives are also found to show bronco-dilatory properties (Jindal et al., 2002). Using tumor necrosis factor- $a$ (TNF- $a$ ) as the biomedical pathway, ethyl 4-(2-carbamoyl anilino) quinazoline-2-carboxylate was discovered to be a promising anti-inflammatory quinazoline derivative with $68 \%$ average inhibition on PDE4B enzyme at concentration of $10 \mu \mathrm{M}$ (Serya et al., 2015).

\section{Antileishmanial activity}

Leishmaniasis, otherwise known as African trypanosomiasis or Chagas disease are vector-borne infectious diseases whose causative agent are parasites of the kinetoplastida order (WHO, 2016; Mendoza-Martínez et al., 2015). It is quite alarming to note that approximately 1.5 million of new cases of cutaneous leishmaniasis emerge every year while there is an outbreak of about 500000 of new cases of visceral diseases in similar vein. Statistics have shown that cutaneous leishmaniasis is endemic over 70 countries of the World today (Tiumana et al., 2011). Comprehensive review of anti-leishmanial drugs discovered for the last decade projected quinazoline as highly promising in this regard (Sangshetti et al., 2015). A series of quina-zoline-2,4,6triamine were synthesized and evaluated in vitro against Leishmania mexicana. Among them, $\mathrm{N}^{6}$ (ferrocenmethyl)quinazolin-2,4,6-triamine showed activity on promastigotes and intracellular amastigotes as well as low cytotoxicity in mammalian cells (Mendoza-Martínez et al., 2015) as shown in Figure 5. In the recent review by Sangshetti et al. (2015) about anti-leishmanial drug discovery, quinazoline core was not left out.

\section{Antitumor activity}

Literature survey revealed that 4-anilinoquinazoline and quinazolinone derivatives are important scaffold used in drug design of effective antitumor agents (Hassan et al., 2015). Structure-activity relationship studies have revealed the significant role of 4 -anilino substituent in the antitumor diversity of quinazoline motifs. From the screening of a series of structurally related 4-anilinoquinazoline with $N$-adamantyl formamide in 4-position 10a-f; specifically, compound $\operatorname{10d}\left(\mathrm{R}_{1}=\mathrm{H} ; \mathrm{R}_{2}=\mathrm{Cl} ; \mathrm{R}_{3}=4\right.$-morpholinyl- $\left(\mathrm{CH}_{2}\right)_{3} ; \mathrm{R}_{4}=$ $\mathrm{CH}_{3}$ ), with an $\mathrm{IC}_{50}$ value of $2.06 \mu \mathrm{M}$ against $\mathrm{A} 431$ cells with the wild-type EGFR and of $0.009 \mu \mathrm{M}$ against the gefitinib-sensitive cells (Mendoza-Martínez et al., 2015) (Figure 6). It displayed efficacy that was about 5-fold active than the lead compound to inhibit the growth of the cells harboring the EGFR (T790M) mutant (Yu et al., 2016; Mendoza-Martínez et al., 2015). The synthesis, structural elucidation as well as in vitro antitumor properties of ruthenium(ii) polypyridyl complexes of 4anilinoquinazolines was recently reported (Du et al., 2016). The reported complexes exhibited substantial enhancement in antitumor activity compared to their precursor ruthenium polypyridyl moieties. They also displayed a dual-targeting manner that can both bind to the DNA minor groove and inhibit EGFR (Du et al., 2016). Caspase-3 activity and cell cycle regulation studies revealed that 4 -anilinoquinazoline $\mathbf{1 1}$ exerted antitumor properties with $\mathrm{IC}_{50}$ of $3.4 \mu \mathrm{M}$ (Palop et al., 2013). Compared with the parental dasatinib, most of the new compounds synthesized by Cai et al. (2013), especially 2,4,6-trimethylaniline 12, demonstrated significant antitumor activities against six cell lines (Figure 7).

\section{Kinase inhibitory activity}

A series of benzimidazole-based quinazoline derivatives were reported to serve as active inhibitor of Aurora according to the investigation carried out through structure-activity relationship (SAR) and quantitative structure-activity relationship (QSAR) 


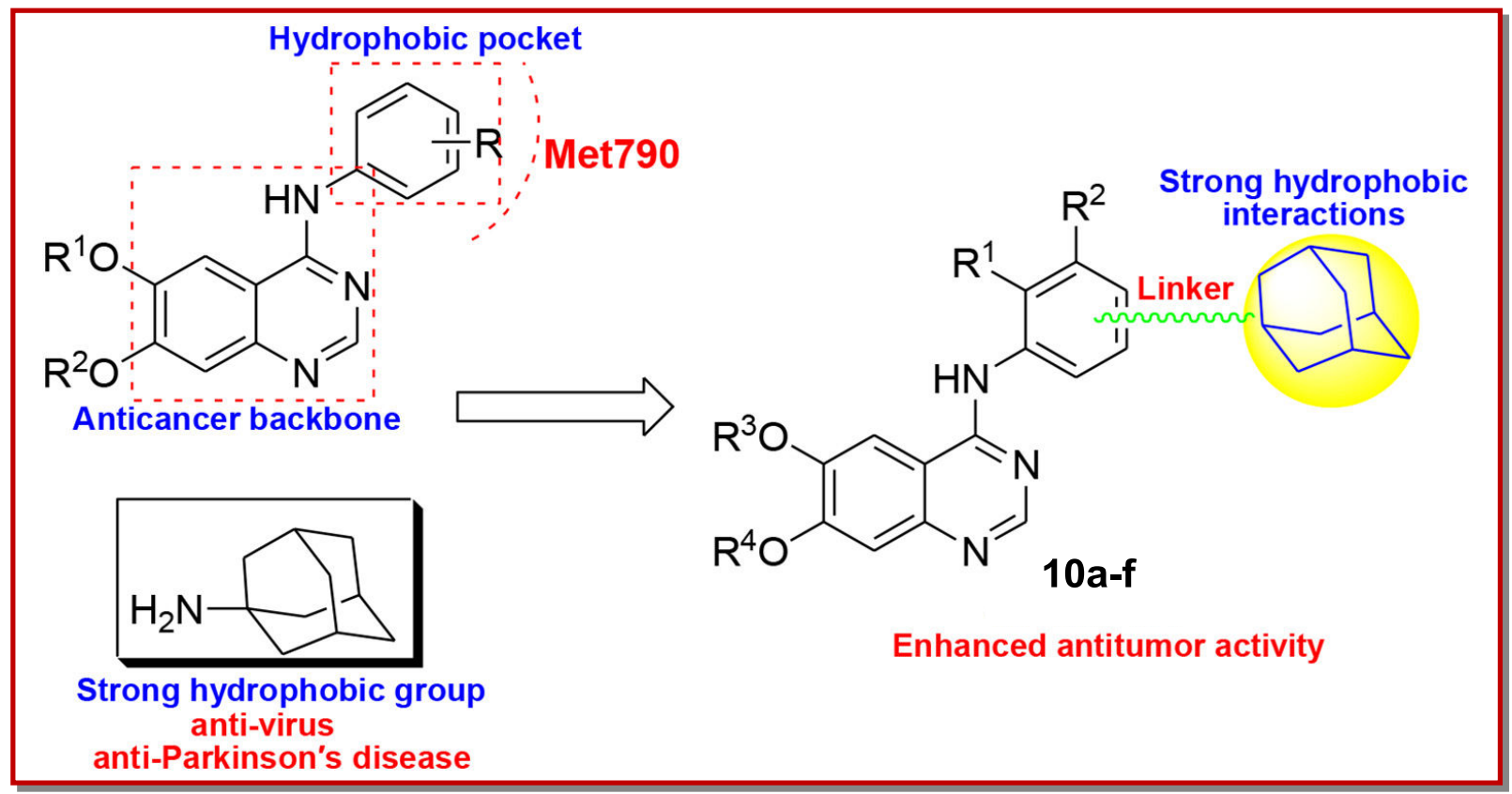

Figure 6: SAR study showing the significant role of 4-anilinoquinazoline as antitumor

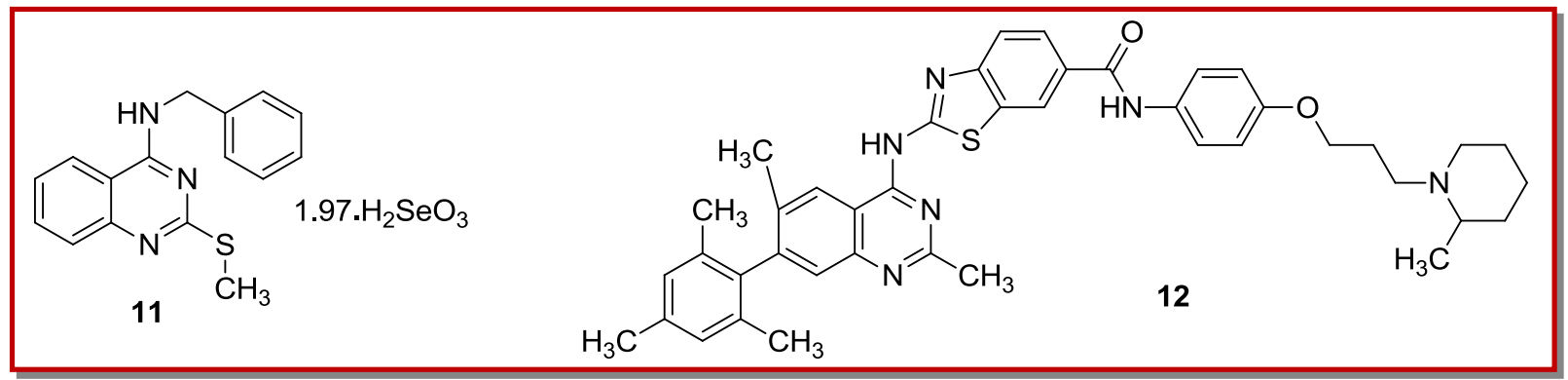

Figure 7: Some quinazoline motifs with antitumor activity

studies (Sharma et al., 2016). Their noticed activity depended on the nature of various substitution patterns of the amine which was present in C2 position of this heterocycles (Sharma et al., 2016). They were established to exhibit improved efficacy as Aurora kinase inhibitors, with $\mathrm{IC}_{50}$ values between 0.035 and $0.532 \mu \mathrm{M}$ (Sharma et al., 2016). The erythropoietinreleasing hepatocellular (Eph) receptor tyrosine kinases was documented to be of great significance in many physiological and pathological actions (Lim et al., 2014). Compound $\mathbf{1 3}$ provided a potent starting point $\left(\mathrm{IC}_{50}=\right.$ $12 \mathrm{nM}$ ) for inhibition of Mps1 kinase with submicromolar cellular toxicity, reduced $\mathrm{MW}$ and TPSA, while 14 provided a further boost in biochemical potency with $\mathrm{IC}_{50}=2 \mathrm{nM}$ (Bursavich et al., 2013). Thus, the comparative study of the two structurally related quinazoline revealed that presence of methylsulfonamide along the axis of 2-substitutent is crucial for enhanced kinase inhibitory activity (Figure 8).

\section{Anticonvulsant activity}

Epilepsy is in fact several disorderly phenomena which is identified through neuronal hyperexcitability as well as neuronal firing. Statistics have shown it to be a terrible menace affecting one percentage of global population (King et al., 2011; Chen et al., 2007). The anticonvulsants used to treat this condition are known as antiepileptic drugs and are among the most widely used drugs for the treatment of central nervous system disorders. New fluorinated quinazolinone motifs have been reported as promising anticonvulsant in this regard (Zayed, 2014). The outcome of MES and PTZ screening carried out on $N$-(substituted)-1-methyl-2,4d i o x o - 1, 2 - d i h y d r o quinazoline - 3 ( $4 \mathrm{H})$ carboxamides unveiled them to possess improved and better anticonvulsant activity when compared with clinical standard drugs which are valproate and methaqualone (Deepakumari et al., 2016). Methaqualone $\mathbf{1 5}$ as a quinazoline analog is an important landmark in the field of synthetic anticonvulsants (Kashaw et al., 2009). The modification of 15 was carried out by El-Azab et al. (2013) to obtain quinazolinone scaffold 16 which proved to be 2 -fold more active than anticonvulsant drug sodium valproate. According to the findings of El-Azab and El- 


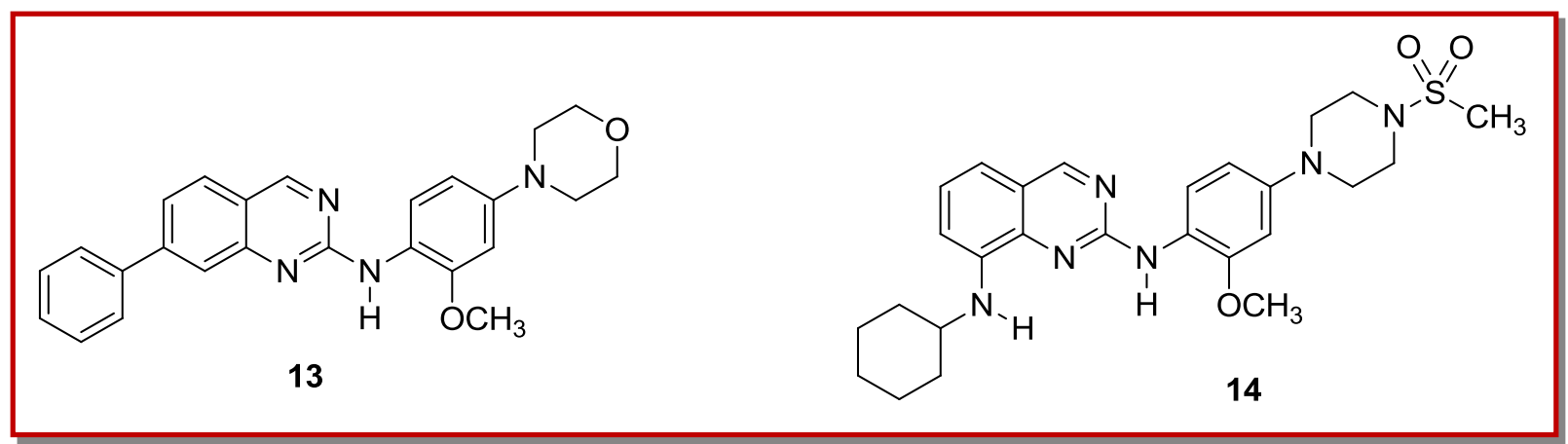

Figure 8: Some quinazoline motifs with kinase inhibitory activity

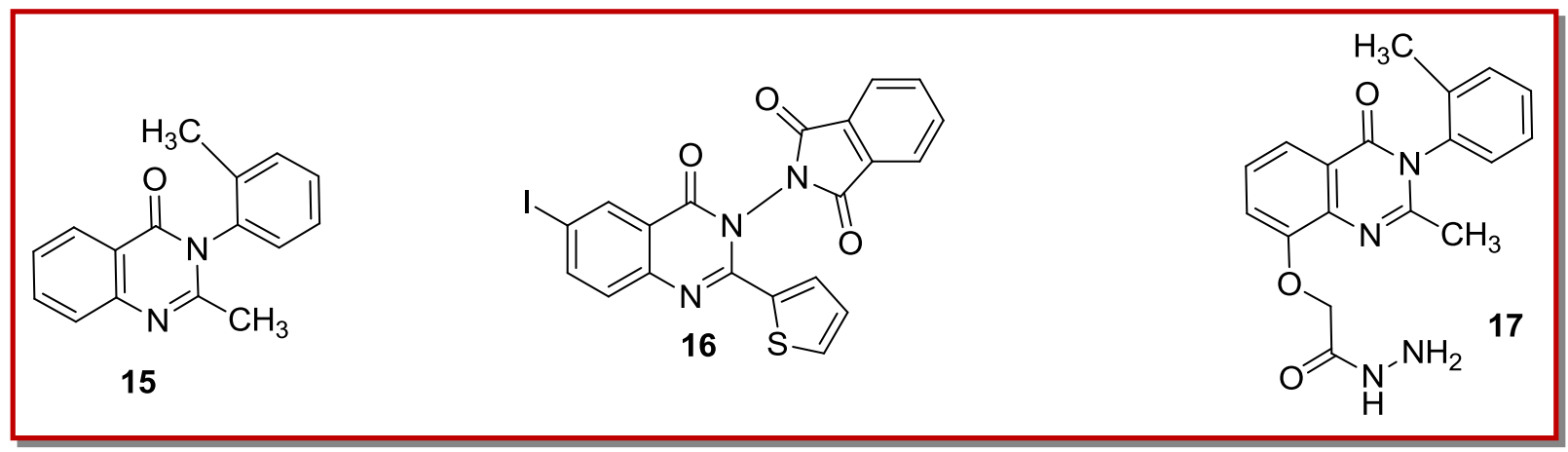

Figure 9: Some quinazoline motifs with anticonvulsant activity

Tahir, (2012), 8-substituted-4(3H)-quinazolinone 17 demonstrated a better anticonvulsant activity and lower toxicity than the reference drugs (Figure 9).

\section{Antimalarial activity}

Malaria is a well-known parasitic disease in tropical regions of the World affecting billons of global population today (Birhan et al., 2015; Franklin et al., 2011). Taking drug resistant challenge into consideration, an impressive and violent universal attempt is continuously engaged for efficient development new antiplasmodial drugs for treatment of this well-known illness (Birhan et al., 2015; Olliaro and Wells, 2009). Although, the volume of cases and mortality rate linked with his illness are reducing according to recent update, yet it is the deadliest disease known globally (Birhan et al., 2015). The in vivo antimalarial activities of the series of quinazolines evaluated with the aid of 4 days suppressive standard experiment against mice infected with Plasmodium berghei ANKA which were chloroquinesensitive isolates revealed that 3-aryl-2(substitutedstyryl)-4(3H)-quinazolinones possessed improved and enhanced antimalarial properties activities having mean suppression of $67.6 \%$ (Birhan et al., 2015). The mean parasitemia level in mice treated with this compound $(17.7 \pm 0.4)$ was noticed to have been 4 times lesser than that of negative control (65.2 \pm 0.7$)$ (Birhan et al., 2015). This shoed that the targeted compounds have significantly decreased parasite load (Birhan et al., 2015). Previous studies showed that the presence of amino substituents on positions 2 and 4, enhanced the antimalarial potential of 6-substituted quinazoline (Rojas-Aguirre et al., 2012; Jäntschi and Bolboacă, 2006). Hence, this led to the strong effect of quinazoline derivative $\mathbf{1 8}$ as an antimalarial motif on human erythrocytes and on cell membrane molecular model (Rojas-Aguirre et al., 2012). Likewise, antimalarial activity of quinazoline 19 was reported to be by topological and geometrical nature and was strongly dependent on partial changes as predicted by MDF SAR methodology (Jäntschi and Bolboacă, 2006). Nonetheless, for the pyrrolo[3,2-f] quinazoline 20, acetamido moieties on positions 2 and 4 was an essential pharmacophoric framework for magical anti-plasmodial potential work in another study (Guan et al., 2005; Figure 10).

\section{HDAC inhibitory activity}

HDACs and histone acetyltransferases (HATs) work in contrary to altered chromatin and therefore provide a guidance for gene expression (Lin et al., 2016; Pickup et al., 2013). HDACs could forcefully suppress the transfer of genetic code through existence of chromatin condensation with regard to in response to the dismissal of acetyl functionality from histone ends (Lin et al., 2016; Bolden et al., 2006). A quinazoline-based HDAC inhibitor was reported to affect genetically expressed routes towards cholesterol biosynthesis via mevalonate within prostate cancer cells (Lin et al., 


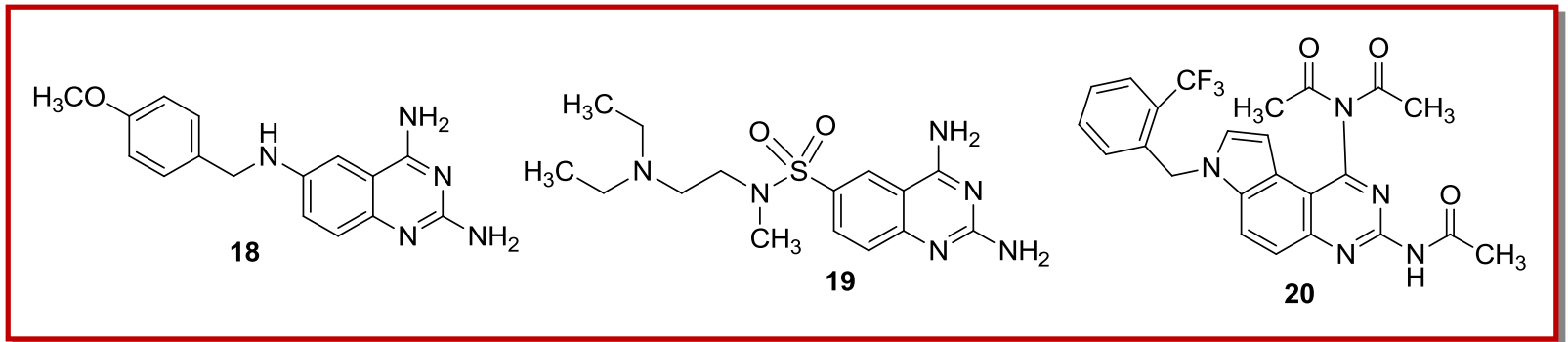

Figure 10: Some quinazoline motifs with antimalarial activity<smiles>COc1cc2ncnc(Nc3ccc(CCC(=O)NO)cc3)c2cc1OCCCN1CCOCC1</smiles><smiles>COc1cc2ncnc(Nc3cccc(/C=C/C(=O)NO)c3)c2cc1OCCCN1CCOCC1</smiles>

Figure 11: Some quinazoline motifs which served as HDAC inhibitors

2016). Histone deacetylases (HDAC) play crucial roles in numerous biological processes; hence, HDAC inhibitory potential of two structurally related quinazoline $\mathbf{2 1}$ and $\mathbf{2 2}$ was compared based on the effect of the substituents on the anilino-phenyl at 4position of quinazoline. The encouraged activity of compound 21 against HDAC (Zhang et al., 2013b) concurred with established fact that hydroxamic acid commonly exhibit better efficacy as HDAC inhibitor than carboxyl-based ones (Zhang et al., 2013b; Kramer, 2009) while quinazoline 22 with meta-substitution and unsaturation near hydroxamic showed even more potency with $\mathrm{IC}_{50}$ of $0.2 \pm 0.02 \mu \mathrm{M}$ (Zhang et al., 2013b) (Figure 11).

\section{Anti-HIV activity}

HIV-1 is an etiological agent of AIDS which is universal pandemic disease that has led to the death of over 34 million of the world population (Famiglini and Silvestri, 2016). In 2014 alone, AIDS was responsible for approximately 1.2 million mortality cases reported globally in 2014 (WHO, 2015). Review by Famiglini and Silvestri, (2016) exemplified many studies carried out on the evaluation of influence of chirality upon antiretroviral properties of highly rated HIV-1 NNRTI molecules, which include alkenyl substituted quinazolinone and nevirapine (Famiglini and Silvestri, 2016). The chiral segregation, enantiospecific synthesis, in addition to biological activity of the HIV-1 NNRTIs were fully expatiated (Famiglini and Silvestri, 2016). An array of new quinazoline-triazine scaffolds were prepared from the reaction of cyanuric halide and anthranilic acid via a sequential pathway (Mendoza-
Martínez et al., 2015) and confirmed to possess encouraging anti-HIV activity (Modh et al., 2014). A series of dihydrobenzo[H]quinazol ine derivatives were synthesized by Mohamed et al. (2012) for the purpose of anti-HIV examination. They reported that 4-thiophen -2-ylquinazoline derivative $\left(\mathrm{IC}_{50}=2.1 \mu \mathrm{M}\right)$ emerged as the best anti-HIV among the series with therapeutic index of $1.9 \times 10^{5}$. Concerning the mechanism of action as anti-HIV, these compounds were reverse transcriptase inhibitors.

\section{Phosphodiesterase (PDE) inhibitors}

PDE groups possess numerous variants which are commonly special tissue-expression traits, gene controlling, enzymatic regulation via phosphorylation and regulatory proteins, subcellular localization, as well as collaboration with association proteins (Omori and Kotera, 2007). Mono-substitution on position 6 of quinazoline core was crucial for effective inhibition wherein substituents of priority which possessed tight package and hydrophobicity are: Methoxy $\left(\mathbf{2 3 b}, \mathrm{IC}_{50}=\right.$ $0.23 \mu \mathrm{M})$, methyl $(23 \mathrm{c}, 0.10 \mu \mathrm{M})$, chloro $(23 \mathrm{~d}, 0.019 \mu \mathrm{M})$, thiomethyl (23f, $0.031 \mu \mathrm{M})$, and cyano $(\mathbf{2 3 p}, 0.090 \mu \mathrm{M})$ functionalities (Takase et al., 1994) as shown in Figure 12. Administration of 3-substitutedquinazolin-2,4dithione as optimized PDE7 inhibitor improved brain damage and enhanced behavioral aftermath in a permanent middle cerebral artery obstruction (pMCAO) stroke model (Redondo et al., 2012; Susín et al., 2012). Sánchez et al. (2013) reported the inhibitory potencies of quinazoline-4-thione $\mathbf{2 4}$ at submicromolar levels against the catalytic domain of PDE7. Smallmolecule phosphodiesterase probe investigation 


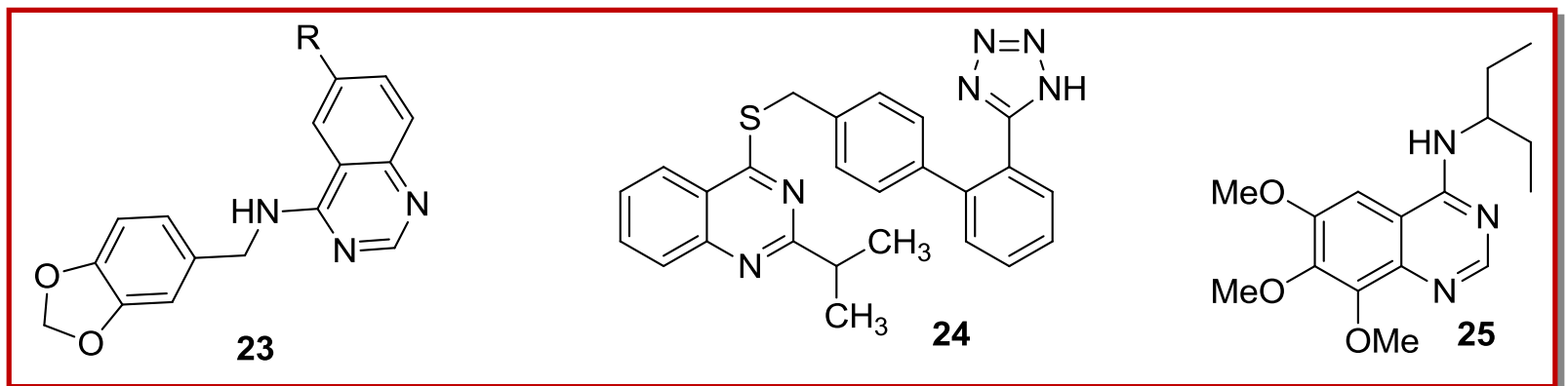

Figure 12: Selected quinazoline motifs with notable PDE inhibitory efficiency

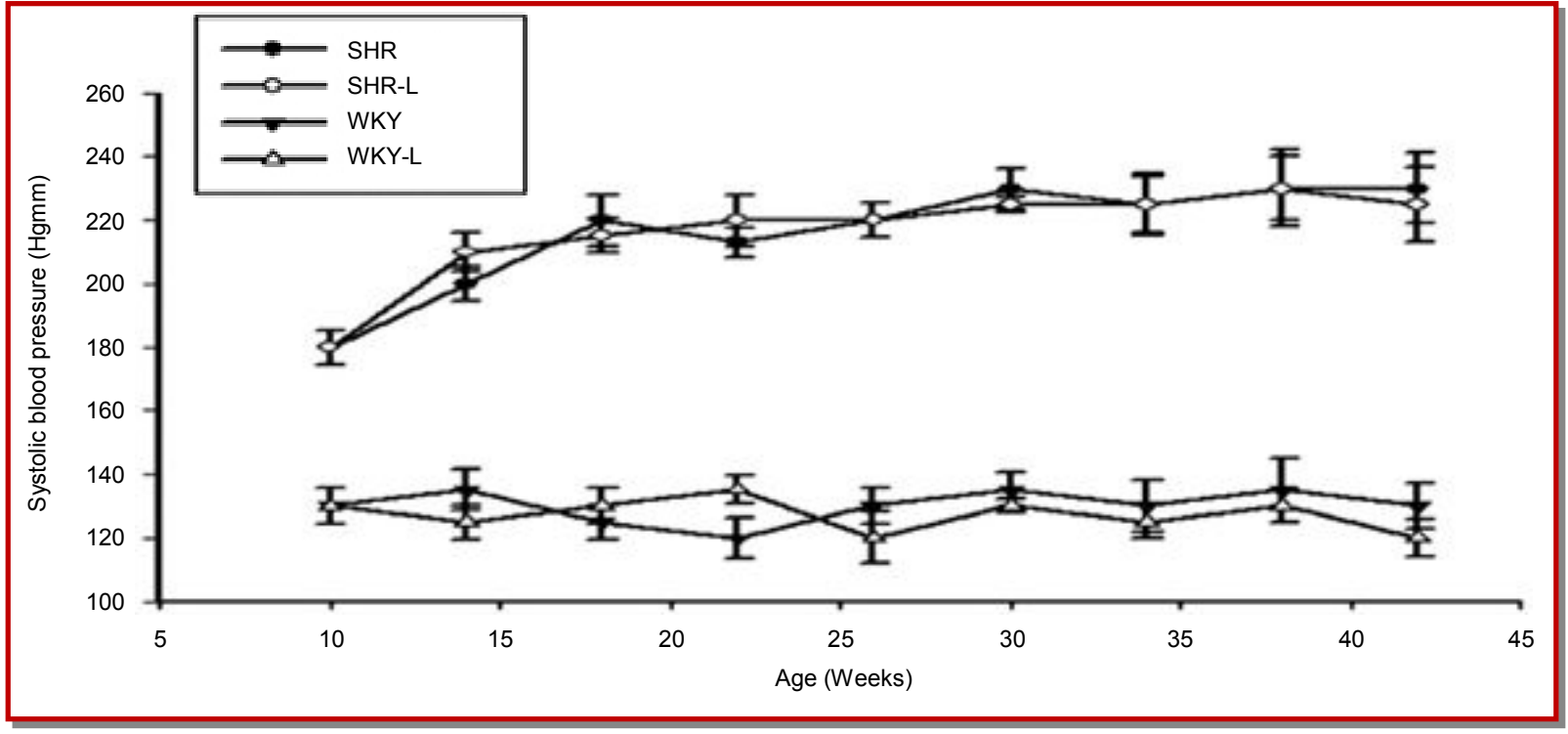

Figure 13: SBP values of normotensive (WKY-C, WKY-L) and hypertensive (SHR-C, SHR-L) rats. Values are means \pm SEM. * $\mathrm{p}<0.05$ (Magyar et al., 2014)

established 4-aminoquinazoline 25 as PDE1 inhibitors that readily cross the blood brain barrier (Humphrey et al., 2014).

\section{Antihypertensive activity}

Hypertension is well-known to be major community health challenge among both middle-aged and older population (Deadwania, 2011). The administration of L2286 in hypertensive animals has been hypothesized to decrease oxidative stress, modulate signaling pathways (PI-3K-Akt, MAP kinases) and attenuate NF-KB activation, thereby reduces the hypertension-induced adverse vascular changes (Magyar et al., 2014). It is well established that PARP inhibitors can prevent oxidative stress induced tissue damage; they can favorably modulate PI-3-kinase/Akt-1 and MAP kinase pathways, and inhibit NF-kB activation (Radnai et al., 2012). Although, PARP inhibition did not have any antihypertensive effect, it enforces salient safeguarding upon process of change of hypertensive heart disorder to heart failure in SHRs (Magyar et al., 2014; Bartha et al., 2009). A series of novel substituted quinazolin-4(3H) -one derivatives, with acute $\mathrm{LD}_{50}>1000 \mathrm{mg} / \mathrm{kg}$, showed enhanced bioactivity than standard drug prazosin, which plays unique role as anti-hypertensive agent through a1 blocking procedure (Pathak et al., 2014). The effect of L-2286 on systolic blood pressure (SBP) was investigated by Magyar et al. (2014). It was discovered that within 32 week of experimental duration, SBP of hypertensive (SHR-C, SHR-L) rats was remarkably greater as compared with normotensive (WKY) rats (Magyar et al., 2014) and the detail of the finding is shown in Figure 13. Administering L-2286 was noticed to contribute no significant change to SBP of SHR rats during the 32 week treatment period (Magyar et al., 2014).

\section{Melanin-concentrating hormone receptor 1 antagonists}

Obesity is a chronic universal epidemic disease (Pokin et al., 2012) which affects a large number of people globally. Over the past 30 years in United States; $60 \%$ of adults are currently either obese or overweight (Hurt et al., 2010). Based on recent National Health and Nutrition Examination Survey, it was established that great than one-third of the adults $(36 \%)$ population in US are obese due to body mass index (BMI) above 30 $\mathrm{kg} / \mathrm{m}^{2}$ (Högberg et al., 2012). Melanin-concentrating hormone $(\mathrm{MCH})$ is a crucial mediator of energy 


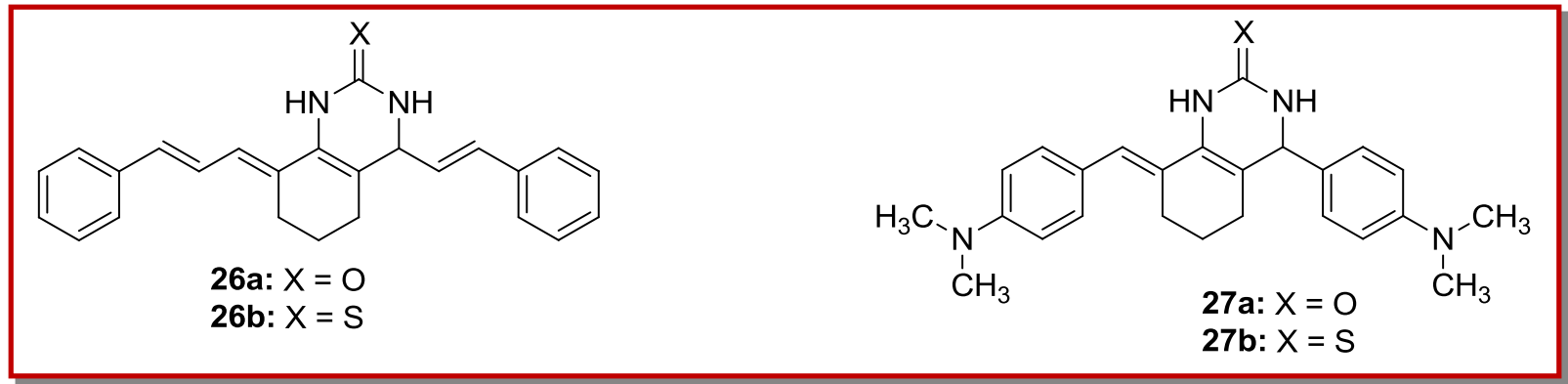

Figure 14: Selected bischalcones with cathepsin inhibitory activity<smiles>[X]c1cc([X])c2nc([R2])n([R1])c(=O)c2c1</smiles>

Figure 15: Selected quinazoline motifs with antibacterial activity

homeostasis (Jeon and Cheon, 2009) which stimulates ingested food in mice upon intra cerebro-ventricular (icv) injection. Hence, Melanin-concentrating hormone receptor 1 (MCHR1) antagonist was reported to be a viable option for the treatment of obesity (Högberg et al., 2012). Melanin-concentrating hormone receptor 1 (MCHR1) antagonising quinazoline derivatives were authenticated to exhibit remarkable and significant antiobesity properties (Sasmal et al., 2012). Pharmacokinetic profile showed that oral administration of $30 \mathrm{mg} / \mathrm{kg}$ b.i.d. of 4-morpholinyl quinazoline led to $12 \%$ weight reduction within fourteen days in DIOC57BL/6 J mice. 4-Amino-2-cyclohexyl aminoquinazoline and 4dimethylaminoquinazoline were reported to exhibit highly promising anti-obesity for suitable weight loss programme due to their good affinity for human MCHR1 (Kanuma et al., 2005).

\section{Cathepsin inhibitory activity}

Bischalcones containing 2(1H)-quinazolinones and 2 $(1 H)$-quinazolinethiones analogs were designed and evaluated for inhibitory potential (Khan et al., 2015) against cathepsin B and cathepsin H (Raghav and Singh, 2014). It was found that 26a $(X=O)$ showed maximum inhibition at $0.1 \mathrm{nM}$ while the thione analog 26b $(X=S)$ showed maximum inhibition at $0.05 \mathrm{nM}$ which was 2-fold more active than 79 (Raghav and Singh, 2014). Among quinazoline derivatives, 2,6-bis (4' (dimethylamino)benzylidene)cyclohexanone 27a $(X=$ O) was found to exhibit $100 \%$ inhibition at $0.1 \mathrm{nM}$ which was four times more active than the thione counterpart $27 \mathrm{~b}(X=\mathrm{s})$ with maximum inhibition of $0.025 \mathrm{nM}$ (Figure 14).

\section{Antibacterial activity}

Bacterial resistance to existing drugs is a growing problem in the world. Considerable researches have been performed on the synthesis of new quinazolinone derivatives with potent antibacterial activity against the Gram +ve bacteria via the way they interact within the cell wall and DNA cores (Mohamed et al., 2013). From valuable information gathered by a previous review, structure activity relationship studies of quinazolinone derivatives in various literatures have revealed that substitution at positions 2 and 3, existence of halogen atom at 6 and 8 positions and substitution (mainly amine or substituted amine) at 4th position of the quinazolinone ring can improve their antimicrobial activities (Jafari et al., 2016). For instance, the primary in vitro bioassay at $100 \mathrm{mg} / \mathrm{mL}$ against tobacco and tomato bacterial wilt revealed 2,3-disubstituted quinazolin-4-one 28 (Wang et al., 2014) as strong antibacterial agents using turbidimeter test (Wang et al., 2013) According to the findings of Liu et al. (2014), 4,6disubstituted quinazoline metabolite, lapatin B 29 showed moderate inhibitory activity against aquapathogenic bacteria Vibrio harveyi (Figure 15).

\section{Antifungal activity}

Three-component design of quinazolinone scaffolds bearing 3-acrylamino side chain was evaluated with the aid of catalytic amount of $\mathrm{CeO}_{2}$ nanoparticles followed by in vitro screening of the targeted quinazolinone for antifungal potential upon selected phytopathogenic fungi (Zhang et al., 2016). The importance of amide was verified and docking study revealed the potential antifungal mechanism of action of the quinazolinone was via chitinase inhibition (Zhang et al., 2016). Among quinazoline examined upon Candida, Aspergillus species and Cryptococcus neoformans, most of 5-hydroxy-furo[2,3 -f]quinazolines showed good antifungal activity by complete inhibition of the growth of Candida 
and Aspergillus species when examined at the MIC value $12.5 \mu \mathrm{g} / \mathrm{mL}$ (Ryu et al., 2012). In another study, a series of benzo[ $h]$ thiazolo[2,3- $b$ ]quinazolinone designed and successfully evaluated for their antifungal activity (Gali et al., 2014) while SAR analysis of some tetrazolo [1,5-c]quinazoline-5-thione derivatives for their inhibitory activity against Candida albicans, show them to be very potent at concentration of $100 \mu \mathrm{g}$ (Antypenko et al., 2013).

\section{Antiviral activity}

Viral diseases threaten latest therapeutic breakthrough because of high mutation rates found among viruses, which empower them to escape immune systems and develop resistance to old existing commercially available drugs (Al-Salahi et al., 2016; Jaime et al., 2013). Benzoquinazoline compounds have been reported to exhibit an interesting antiviral activity which was why evaluation of recently prepared 2-thioxo-based benzo[ $g]$ quinazolin-4 $(3 H)$-ones was reported against herpes simplex and coxsackie virus (Al-Salahi et al., 2016). Systematic evaluation of a series of thioquinazoline against Tobacco Mosaic Virus (TMV) led to the discovery of quinazolin-4-yl based prop-2-en-1-one that exhibited encouraging protection properties $(\mathrm{EC} 50=$ $138.1 \mu \mathrm{g} / \mathrm{mL}$ ) upon TMV in vivo, which was over three times more active than Ribavirin $($ EC50 $=436.0 \mu \mathrm{g} / \mathrm{mL})$ standard (Wan et al., 2015). A series of quinazoline prepared via Schiff bases formation were screened against herpes simplex virus-1 (KOS), virus-2 (G) and vaccinia virus (Ali et al., 2007), wherein (E)-3-((2hydroxybenzylidene) amino)-2-phenyl quinazolin-4 $(3 \mathrm{H})$-one emerged as the most promising antiviral motif against the entire tested virus (Kumar et al., 2010). It has also been reported that high indicator of the antiviral activity of $N$-methyl-2-((2-oxo-3-phenyl-2H-[1,2,4]triazino[2,3-c]quinazolin-6-yl)thio)acetamide (Kolavenko et al., 2013) bearing-adamantane against influenza type A $\mathrm{H} 3 \mathrm{~N} 2$ was due to insertion of carcass amine.

\section{Anti-oxidant activity}

Reactive oxygen species (ROS) which include ${ }^{1} \mathrm{O}_{2}, \mathrm{O}_{2}$ and $\mathrm{OH}$ free radicals and hydrogen $\mathrm{H}_{2} \mathrm{O}_{2}$ were commonly produced as side products from either biochemical interaction or through exogenous factors (Sergey et al., 2010). ROS play a vital role as far as aging and pathogenetic traits of age responsive diseases are concerned (Vagdevi et al., 2012; Manasa et al., 2011). An array of quinazoline-2,4-dione Schiff bases were reported to possess over $50 \%$ inhibitory efficiency upon $\mathrm{DPPH}\left(\mathrm{IC}_{50}=25-50 \mu \mathrm{g} / \mathrm{mL}\right)$ and most of the compounds showed a dose dependent behavior in FRAP assay (Vagdevi et al., 2012). 2-Methyl-3-(pyrrolidin-2ylidene amino)quinazolin-4(3H)-one was reported to be much higher in activity compared with ascorbic acid standard (Al-Azawi, 2016). It also served as a powerful and highly resourceful scavenger against $\mathrm{DPPH}$ and
Nitric oxide (Al-Azawi, 2016).

\section{Antidiabetic activity}

Due to widespread nature of diabetes mellitus globally, a great deal of effort in applied research is on-going for the discovery of new heterocyclic molecules as antidiabetic agents with a well detailed information on its mode of action (Islam and Loot, 2009; Cheng, 2005). Sublethal dosage testing for 1-thioxo-1,2,7,8,9,10-hexahydro-3H-pyrimido[1,6-a]quinazolin-3-one showed that it has remarkable potential in (n-STZ) diabetic male as antihyperglycemic agent (Ahmed et al., 2012). The (nSTZ) diabetic male model used in the study acquired biological and pathological diagnostic sign related to the type 2 diabetes in mankind (Islam and Loot, 2009). The one-pot synthesis of a series of quinazolin-4-one in the presence of $\left[\mathrm{BMIM}^{+}\right]\left[\mathrm{BF}_{4}^{-}\right]$as green and reusable catalyst was reported and the attempted investigation of antidiabetic activity showed 3-(5-bromopyridin-2-yl) quinazolin- $4(3 H)$-one to be the most active in this series (Dongamanti et al., 2012).

\section{Antithrombosis activity}

Activated factor $\mathrm{X}(\mathrm{FXa})$ is a formidable player in thrombin generation through coagulation cascade responsibility during the process of atrial fibrillation (Bukowska et al., 2013). Activated factor X FXa and tachyarrhythmia act synergistically to increase expression of protease-activated receptors and inflammatory mediators (Bukowska et al., 2013). Some quinazoline derivative exerted inhibition of inflammation via this route. Elinogrel 30, the structure shown in Figure 16 is a marketed available antithrombosis drug containing quinazolinone moiety (Nayyar and Arpanarana, 2011).

\section{Structure-activity relationship study (SAR)}

The SAR study carried out on the selected molecules showed that electron-withdrawing and electron-donating could inform a synthetic chemist about the choice of a suitable substitution pattern. Some heterocyclic moieties attachments are the basic templates responsible for the regulation of biological activity of targeted quinazoline derivative synthesized. From the painstaking examination of the SAR, it was collectively noted that the positions 2, 4 and 6 are major points of biological relevance for improved activities for possible drug design (Wang and Gao, 2013). Various 2,4,6trisubstituted positions of quinazoline derivatives have been evaluated as essential pharmacophoric placement for the enhancement of bioactivity (Chandrika et al., 2009). In addition, the substitution on the pyrimidine ring shows more of an antimalarial activity variation of a quinazoline derivative (Khan et al., 2014). Triazolofused quinazoline 31 with morpholinyl in 2-position and chloro on 6-position was the most potent antimicrobial scaffold among the series synthesized by Jantova et al, (2005). Presence of electron donating 
<smiles>CNc1cc2[nH]c(=O)n(-c3ccc(NC(=O)CS(=O)(=O)c4ccc(Cl)s4)cc3)c(=O)c2cc1F</smiles>

Figure 16: Elinogrel as selected quinazoline-based antithrombotic marketed drug

diamine at 4-position increased the anti-inflammatory efficacy of 32 (Lin et al., 2010). Polar functionality like hydroxamate when inserted at position- 4 of quinazoline templates, core was reported to probably provide a very active HDACi/HER2i hybrid as seen in $\mathbf{3 3}$ which was the most potent HDAC inhibitor among the quinazolines designed and synthesized by Zhang et al. (2013b). Some structural representations of quinazoline templates for SAR study are as shown in Figure 17.

\section{Conclusion}

It is reported that in recent times lots of pathogens and causative agent of diseases have grown resistant abilities to the old existing and commercially available drugs, which have made the cure of these diseases harder and almost impossible. Quinazoline derivatives are considered as important precursors for the synthesis of various physiologically significant and pharmacologically utilized molecules. This present article provides the researchers with a pool of diagnostic information in quinazoline templates and thorough understanding of their structure activity relationship study in order to help mankind against the adverse effect of drug-resistance pathogens and newly occurring infectious diseases. This further helps in designing large number of quinazoline and quinazolinone compounds with a strong impact in curing many fatal disorders and infectious diseases. Quinazoline derivatives are therefore projected as valuable tools for the development of novel pharmacological entities treatment of diverse infectious diseases and disorder in the therapeutic medicine.

\section{Conflict of Interest}

Authors hereby declare that there are no conflict of interest as regard to this work.

\section{References}

Ahmed OM, Hussein AM, Ahmed RR. Antidiabetic and antioxidant effects of newly synthesized pyrimido[1,6-a]pyrimidine derivatives in neonatal streptozotocin-induced diabetic Rats. Med Chem. 2012; 2: 20-28.

Ajani OO. Present status of quinoxaline motifs: Excellent pathfinders in therapeutic medicine. Eur J Med Chem. 2014; 85: 688-715.

Ajani OO, Nwinyi OC. Synthesis and evaluation of antimicrobial activity of phenyl and furan-2-yl[1,2,4]triazolo[4,3-a] quinoxalin-4 $(5 \mathrm{H})$-one and their hydrazone precursors. Canadian J Pure Appl Sci. 2009; 3: 983-92.

Alafeefy AM, Ceruso M, Al-Tamimi AMS, Prete SD, Capasso C, Supuran, CT. Quinazoline-sulfonamides with potent inhibitory activity against the a-carbonic anhydrase from Vibrio cholera. Bioorg Med Chem. 2014; 22: 5133-40.

Al-Azawi K. Synthesis, characterization and anti-oxidant studies of quinazolin derivatives. Orient J Chem. 2016; 32: 585-90.

Ali MA, Shaharyar M, De Clercq E. Synthesis of 5-(4-hydroxy3-methylphenyl)-5-(substitutedphenyl)-4, 5-dihydro-1H-1pyrazolyl-4-pyridylmethanone derivatives with antiviral activity. J Enzym Inhib Med Chem. 2007; 22: 702-08.

Al-Omary FA, Hassan GS, El-Messery SM, El-Subbagh HI. Substituted thiazoles V. synthesis and antitumor activity of novel thiazolo[2,3-b]quinazoline and pyrido[4,3-d]thiazolo [3,2-a]pyrimidine analogues. Eur J Med Chem. 2012; 47: 6572 .

Al-Salahi R, Abuelizz HA, Ghabbour HA, El-Dib R, Marzouk M. Molecular docking study and antiviral evaluation of 2thioxo-benzo[g]quinazolin-4(3H)-one derivatives. Chem Cent J. 2016; 10: 21.

Aly MM, Mohamed YA, El-Bayouki KM, Basyouni WM, Abbas S.Y. Synthesis of some new4(3H)-quinazolinone-2carboxaldehyde thiosemicarbazones and their metal complexes and a study on their anticonvulsant, analgesic, cytotoxic and antimicrobial activities. Eur J Med Chem. 2010; 45: 3365-73.

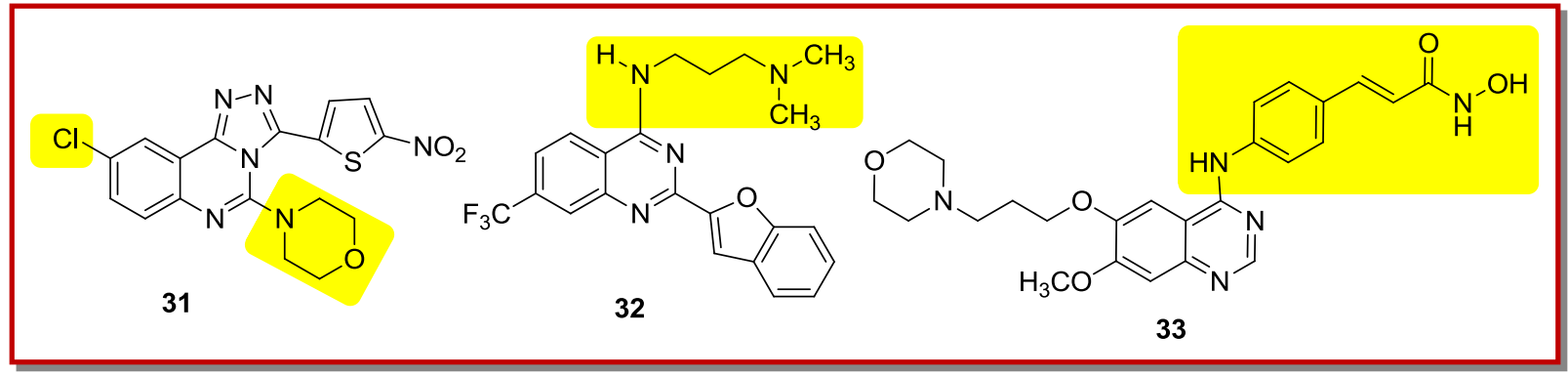

Figure 17: Representative quinazoline motifs for SAR study 
Anand T, Sivaraman G, Chellappa D. Quinazoline copper(II) ensemble as turn-on fluorescence sensor for cysteine and chemodosimeter for NO. J Photochem Photobiol A: Chem. 2014; 281 : 47-52.

Ankita W, Pranay W, Nishi G, Rai AK, Srivastav RS. Novel class of semi synthetic natural products derived from lupeol as antitubercular agents. Stand Res J Pharm Pharmacol. 2014; 2: $40-45$.

Antonello A, Tarozzi A, Morroni F, Cavalli A, Rosini M, Hrelia $\mathrm{P}$, Bolognesi ML, Melchiorre C. Multitarget-directed drug design strategy: A novel molecule designed to block epidermal growth factor receptor (EGFR) and to exert proapoptotic effects. J Med Chem. 2006; 49: 6642-45.

Antypenko LM, Kovalenko SI, Antypenko OM, Katsev AM, Achkasova AM. Design and evaluation of novel antimicrobial and anti-cancer agents among tetrazolo[1,5-c]quinazo line-5-thiones derivatives. Sci Pharm. 2013; 81: 15-52.

Armarego WLF. The chemistry of heterocyclic compounds: Fused pyrimidines, Part 1, quinazolines. New Jersey, John Wiley and Sons Inc., 1967, 24, p 11, 12, 270, 391.

Arya K, Tomar R, Rawat DS. Greener synthesis and photo-anti -proliferative activity of novel fluorinated benzothiazolo[2,3b]quinazoline. Med Chem Res. 2014; 23: 896-904.

Asif M. Chemical characteristics, synthetic methods, and biological potential of quinazoline and quinazolinone derivatives. Int J Med Chem. 2014; 2014: p 27.

Barbosa MLC, Lima LM, Tesch R, Sant'Anna CMR, Totzke F, Kubbutat MHG, Schächtele C, Laufer SA, Barreiro EJ. Novel 2-chloro-4-anilino-quinazoline derivatives as EGFR and VEGFR-2 dual inhibitors. Eur J Med Chem. 2014; 71: 1-14.

Bartha E, Solti I, Kereskai L, Lantos J, Plozer, E, Magyar K, Szabados E, Kalai T, Hideg K, Halmosi R, Sumegi B, Kalman T. PARP inhibition delays transition of hypertensive cardiopathy to heart failure in spontaneously hypertensive rats. Cardiovasc Res. 2009; 83: 501-10.

Birhan YS, Bekhit AA, Hymete A. In vivo antimalarial evaluation of some 2,3-disubstituted-4(3H)-quinazolinone derivatives. BMC Res Notes 2015; 8: 589-94.

Bolden JE, Peart MJ, Johnstone RW. Anti-cancer activities of histone deacetylase inhibitors. Nat Rev Drug Discovery. 2006; 5: 769-84.

Bukowska A, Zacharias I, Weinert S, Skopp K, Hartmann C, Huth C, Goette A. Coagulation factor Xa induces an inflammatory signaling by activation of protease-activated receptors in human atrial tissue. Eur J Pharmacol. 2013; 718: 114-23.

Bursavich MG, Dastrup D, Shenderovich M, Yager KM, Cimbora DM, Williams B., Kumar DV. Novel Mps1 kinase inhibitors: From purine to pyrrolopyrimidine and quinazoline leads. Bioorg Med Chem Lett. 2013; 23: 6829-33.

Cai J, Sun M, Wu X, Chen J, Wang P, Zong X, Ji M. Design and synthesis of novel 4-benzothiazole amino quinazolines dasatinib derivatives as potential antitumor agents. Eur J Med Chem. 2013; 63: 702-12.

Chandrika PM, Yakaiah T, Narsaiah B, Sridhar V, Venugopal G, Rao JV, Kumar KP, Murthy USN, Rao ARR. Synthesis leading to novel 2,4,6-trisubstituted quinazoline derivatives, their antibacterial and cytotoxic activity against THP-1, HL60 and A375 cell lines. Indian J Chem. 2009; 48B: 840-47.

Chandrika PM, Yakaiah T, Rao ARR, Narsaiah B, Reddy NC, Sridhar V, Rao JV. Synthesis of novel 4,6-disubstituted quinazoline derivatives, their anti-inflammatory and anticancer activity (cytotoxic) against U937 leukemia cell lines. Eur J Med Chem. 2008; 43: 846-52.

Chang FR, Lee YH, Yang YL, Hsieh PW, Khalil AT, Chen CY, $\mathrm{Wu}$ YC. Secoiridoid glycoside and alkaloid constituents of hydrangea chinensis. J Nat Prod. 2003; 66: 1245-48.

Chen L, Sun YX, Chai YK, Lee JS, Song MS, Quan ZS. Synthesis and anticonvulsant evaluation of 4-(4-alkoxylphenyl)-3-ethyl $-4 \mathrm{H}-1,2,4$-triazoles as open-chain analogues of 7-alkoxyl-4,5dihydro-1,2,4-triazolo[4,3-a]quinolines. Bioorg Med Chem. 2007; 15: 6775-81.

Cheng D. Prevalence, predisposition and prevention of type II diabetes. Nutr Metab. 2005; 2: 29-39.

Connolly DJ, Cusack D, Sullivan TPO, Guiry PJ. Synthesis of quinazolinones and quinazolines. Tetrahedron. 2005; 61: 10153-202.

Corbett EL, Watt CJ, Walker N, Maher D, Williams BG, Raviglione MC, Dye C. The growing burden of tuberculosis: Global trends and interactions with the HIV epidemic. Arch Intern Med. 2003; 163: 1009-21.

Deepakumari HN, Jayanna BK, Prashanth MK, Revanasiddappa HD, Veeresh B. Synthesis and anticonvulsant activity of $\mathrm{N}$-(substituted)-1-methyl-2,4-dioxo-1,2-dihydroquin azoline -3(4H)-carboxamides. Arch Pharm. 2016.

Deedwania PC, Blood pressure control in diabetes mellitus: Is lower always better, and how low should it go? Circulation 2011; 123: 2776-78.

Ding MW, Yang SJ, Chen YF. Synthesis and fungicidal activities of 2-alkoxy-3H-quinazolin-4-ones. Chinese J Org Chem. 2004; 24: 923-1026.

Dongamanti A, Gadiparthi R, Redamala R, Anireddy J, Burri $\mathrm{N}$, Vantikommu J. Synthesis, antibacterial, anti-asthmatic and anti-diabetic activities of novel 3-substituted quinazolin4-ones using 1-butyl-3-methyl-imidazoliumtetrafluoro borate $\left[\mathrm{BMIM}^{+}\right]\left[\mathrm{BF}_{4}\right]$ as a green, efficient and reusable catalyst under solvent free conditions. J Chem Pharm Res. 2012; 4: 3991-4000.

Du J, Kang Y, Zhao Y, Zheng W, Zhang Y, Lin Y, Wang Z, Wang Y, Luo Q, Wu K, Wang F. Synthesis, characterization, and in vitro antitumor activity of ruthenium(ii) polypyridyl complexes tethering EGFR-inhibiting 4-anilinoquinazolines. Inorg Chem. 2016; 55: 4595-605.

Eicher T, Hauptmann S. The chemistry of heterocycles: Structure, reactions, syntheses, and applications. $2^{\text {nd }}$ edn. 2003.

El-Azab AS, Abdel-Hamide SG, Sayed-Ahmed MM, Hassan GS, El-Hadiyah TM, Al-Shabanah OA, Al-Deeb OA, ElSubbagh HI Novel 4(3H)-quinazolinone analogs: Synthesis and anticonvulsant activity. Med Chem Res. 2013; 22: 281527.

El-Azab AS, ElTahir KEH. Design, synthesis and anticonvulsant evaluation of novel 8-substituted-4(3H)-quinazolines. 
Med Chem Res. 2012; 21: 3785-96.

Elkamhawy A, Lee J, Park BG, Park I, Pae AN, Roh EJ. Novel quinazoline-urea analogues as modulators for $A \beta$-induced mitochondrial dysfunction: Design, synthesis, and molecular docking study. Eur J Med Chem. 2014; 84: 466-75.

Famiglini V, Silvestri R. Focus on chirality of HIV-1 nonnucleoside reverse transcriptase inhibitors. Molecules 2016; 21: 221-39.

Farag AA, Khalifa EM, Sadik NA, Abbas SY, Al-Sehemi AG, Ammar YA. Synthesis, characterization, and evaluation of some novel 4(3H)-quinazolinone derivatives as antiinflammatory and analgesic agents. Med Chem Res. 2013; 22: $440-52$.

Fares M, Eldehna WM, Abou-Seri SM, Abdel-Aziz HA, Aly $\mathrm{MH}$, Tolba MF. Design, synthesis and in vitro antiproliferative activity of novel isatin-quinazoline hybrids. Arch Pharm (Weinheim). 2015; 348: 144-54.

Franklin BS, Ishizaka ST, Lamphier M, Gusovsky F, Hansen H, Rose J, Zheng W, Ataíde MA, de Oliveira RB, Golenbock DT, Gazzinelli RT. Therapeutical targeting of nucleic acidsensing Toll-like receptors prevents experimental cerebral malaria. Proc Natl Acad Sci USA. 2011; 108: 3689-94.

Fung C, Grandis JR. Emerging drugs to treat squamous cell carcinomas of the head and neck. Expert Opin Emerg Drugs. 2010; 15: 355-73.

Gali R, Banothu J, Porika M, Velpula R, Hnamte S, Bavantula $\mathrm{R}$, Abbagani S, Busi S. Indolyl methylenebenzo[h]thiazolo [2,3-b]quinazolinones: Synthesis, characterization and evaluation of anti-cancer and antimicrobial activities. Bioorg Med Chem Lett. 2014; 24: 4239-42.

Garofalo A, Goossens L, Lemoine A, Ravez S, Six P, Howsam, M, Farce A, Depreux P. [4-(6,7-Disubstituted quinazolin-4ylamino)phenyl] carbamic acid esters: A novel series of dual EGFR/VEGFR-2 tyrosine kinase inhibitors. Med Chem Commun. 2011; 2: 65-72.

Ghorab MM, Alsaid MS, Al-Dosari MS, El-Gazzar MG, Parvez MK. Design, synthesis and anti-cancer evaluation of novel quinazoline-sulfonamide hybrids. Molecules 2016; 21: 189200.

Guan J, Zhang Q, O'Neil M, Obaldia III N, Ager A, Gerena L, Lin AJ. Antimalarial activities of new pyrrolo[3,2-f]quinazoline-1,3-diamine derivatives. Antimicrob Agent Chemother. 2005; 49: 4928-33.

Hassan GS, Georgey HH, Ibrahim NA, Zaki SS. Synthesis of novel substituted quinazoline and quinazolin-4(3H)-one derivatives of expected antitumor activity. Der Pharm Chem. 2015; 7: 106-19.

Högberg T, Frimurer TM, Sasmal PK. Melanin-concentrating hormone receptor 1 (MCHR1) antagonists - Still a viable approach for obesity treatment. Bioorg Med Chem Lett. 2012; 22: $6039-47$

Humphrey JM, Yang E, am Ende CW, Arnold EP, Head JL, Jenkinson S, Lebel LA, Liras S, Pandit J, Samas B, Vajdos F, Simons SP, Evdokimov A, Mansour M, Menniti FS. Smallmolecule phosphodiesterase probes: Discovery of potent and selective CNS-penetrable quinazoline inhibitors of PDE1.
Med Chem Commun. 2014; 5: 1290-96.

Hurt RT, Kulisek C, Buchanan LA, McClave SA. the obesity epidemic: Challenges, health initiatives, and implications for gastroenterologists. Gastroenterol Hepatol (N Y). 2010; 6: 780 $-92$.

Hynes NE, Lane HA. ERBB receptors and cancer: The complexity of targeted inhibitors. Nat Rev Cancer. 2005; 5: 341-54.

Islam MS, Loots DT. Experimental rodent models of type 2 diabetes: A review. Methods Find Exp Pharmacol. 2009; 31: 249-61.

Jabir NR, Tabrez S, Ashraf GMd, Shakil S, Damanhouri GA, Kamal MA. Nanotechnology-based approaches in anticancer research. Int J Nanomed. 2012; 7: 4391-408.

Jafari E, Khajouei MR, Hassanzadeh F, Hakimelahi GH, Khodarahmi GA. Quinazolinone and quinazoline derivatives: Recent structures with potent antimicrobial and cytotoxic activities. Res Pharm Sci. 2016; 11: 1-14.

Jaime MFV, Redko F, Muschietti LV, Campos RH, Martino VS, Cavallaro LV. In vitro antiviral activity of plant extracts from Asteraceae medicinal plants. Virol J. 2013; 10: 245.

Jantova S, Ovadekova R, Letasiova S, Spirkova K, Stankovsky S. Antimicrobial activity of some substituted triazoloquinazolines. Folia Microbiol. 2005; 50: 90-94.

Jäntschi L, Bolboacă S. Molecular descriptors family on structure activity relationships 5 . Antimalarial activity of 2,4diamino-6-quinazoline sulfonamide derivates. Leonardo J Sci. 2006; 8: 77-88.

Jeon MK, Cheon HG. Promising strategies for obesity pharmacotherapy: Melanocortin-4 (MC-4)receptor agonists and melanin concentrating hormone $(\mathrm{MCH})$ receptor-1 antagonists. Curr Top Med Chem. 2009; 9: 504-38.

Jindal DP, Bhatti RS, Ahlawat S, Gupta R. Synthesis and bronchodilatory activity of some nitrogen bridgehead compounds. Eur J Med Chem. 2002; 37: 419-25.

Joule JA, Mills K. Heterocyclic chemistry. $4^{\text {th }}$ edn. Oxford, Wiley-Blackwell Publishers, 2000, pp 12-18.

Kanuma K, Omodera K, Nishiguchi M, Funakoshi T, Chaki S, Semple G, Tran TA, Kramer B, Hsu D, Casper M, Thomsen B, Sekiguchi Y. Lead optimization of 4-(dimethyl amino) quinazolines, potent and selective antagonists for the melanin-concentrating hormone receptor 1. Bioorg Med Chem Lett. 2005; 15: 3853-56.

Kashaw SK, Kashaw V, Mishra P, Jain NK, Stables JP. Synthesis, anticonvulsant and CNS depressant activity of some new bioactive 1-(4-substituted-phenyl)-3-(4-oxo-2phenyl /ethyl -4H-quinazolin-3-yl)-urea. Eur J Med Chem. 2009; 44: 4335-43.

Khan I, Ibrar A, Abbas N, Saeed A. Recent advances in the structural library of functionalized quinazoline and quinazolinone scaffolds: Synthetic approaches and multifarious applications. Eur J Med Chem. 2014; 76: 193-244.

Khan I, Ibrar A, Ahmed W, Saeed A. Synthetic approaches, functionalization and therapeutic potential of quinazolineand quinazolinone skeletons: Advance continue. Eur J 
Med Chem. 2015; 90: 124-69.

King AM, Marc DR, Rafal K, Anne V, James PS, Harold K. Defining the structural parameters that confer anticonvulsant activity by the site-by-site modification of (R)- $\mathrm{N}^{\prime}$-benzyl 2-amino-3-methylbutanamide. J Med Chem. 2011; 54: 643242.

Kolavenko SI, Nosulenko IS, Voskoboynik AY, Berest GG, Antypenko LN. Antypenko AN, Katsev AM. Novel N-aryl (alkaryl)-2-[(3-R-2-oxo-2H-[1,2,4] triazino[2,3-c]quinazoline-6yl)thio]acetamides: Synthesis, cytotoxicity, anticancer activity, compare analysis and docking. Med Chem Res. 2013; 22: 2610-32.

Kramer OH. HDAC2: A critical factor in health and disease. Trends Pharmacol Sci. 2009; 30: 647-55.

Kumar A, Ito A, Hirohama M, Yoshida M, Zhang KYJ. Identification of quinazolinyloxy biarylurea as a new class of SUMO activating enzyme 1 inhibitors. Bioorg Med Chem Lett. 2013; 23: 5145-49.

Kumar A, Sharma S, Bajaj AK, Sharma S, Panwar H, Singh T, Srivastava VK. Some new 2, 3, 6-trisubstituted quinazolinones as potent anti-inflammatory, analgesic and COX-II inhibitors. Bioorg Med Chem. 2003; 11: 5293-99.

Kumar KS, Ganguly S, Veerasamy R, De Clercq E. Synthesis, antiviral activity and cytotoxicity evaluation of Schiff bases of some 2-phenyl quinazoline-4(3H)-ones. Eur J Med Chem. 2010; 45: 5474-79.

Lim CJ, Oh KS, Ha JD, Lee JH, Seo HW, Chae CH, Kim DG, Lee MJ, Lee BH. 4-Substituted quinazoline derivatives as novel EphA2 receptor tyrosine kinase inhibitors. Bioorg Med Chem Lett. 2014; 24: 4080-83.

Lin Z, Bishop KS, Sunderland H, Marlow G, Murray P, Dennya WA, Ferguson LR. Aquinazoline-based HDAC inhibitor affects gene expression pathways involved in cholesterol biosynthesis and mevalonate in prostate cancer cells. Mol BioSyst. 2016; 12: 839-49.

Lin Z, Murray PM, Ding Y, Denny WA, Ferguson LR. Quinazolines as novel anti-inflammatoryhistone deacetylase inhibitors. Mutation Res. 2010; 690: 81-88.

Liu J, Xie YQ, Lin Q, Shi BB, Zhang P, Zhang YM, Wei TB. Dipodal fluorescent chemosensor for $\mathrm{Fe}^{3+}$ and resultant complex as a chemosensor for fluoride. Sensor Actuator B Chem. 2013; 186: 657-65.

Liu Y, Li XM, Meng LH, Wang BG. N-Formyllapatin A, a new $\mathrm{N}$-formylspiro quinazoline derivative from the marinederived fungus Penicillium adametzioides AS-53. Phytochem Lett. 2014; 10: 145-48.

Luo H, Yang S, Cai Y, Peng Z, Liu T. Synthesis and biological evaluation of novel 6-chloro-quinazoline derivatives as potential antitumor agents. Eur J Med Chem. 2014; 84: 746-

52.

Magyar K, Deres L, Eros K, Bruszt K, Seress L, Hamar J, Hideg K, Balogh A, Gallyas Jr, F, Sumegi B, Toth K, Halmosi R. A quinazoline-derivative compound with PARP inhibitory effect suppresses hypertension-induced vascular alterations in spontaneously hypertensive rats. Biochim Biophys Acta Mol Basis Dis. 2014; 1842: 935-44.
Mahato AK, Srivastava B, Nithya S. Chemistry, structure activity relationship and biological activity of quinazoline-4 (3H)-one derivatives. Inventi Rapid Med Chem. 2011; 2.

Maheswari CU, Kumar GS, Venkateshwar M, Kumar RA, Kantam ML, Reddy KR. Highly efficient one-pot synthesis of 2 -substituted quinazolines and $4 \mathrm{H}$-benzo[d][1,3]oxazines via cross dehydrogenative coupling using sodium hypochlorite. Adv Syn Catal. 2010; 352: 341-46

Manasa K, Sidhaye RV, Radhika G, Nalini CN. Synthesis, antioxidant and anti-cancer activity of quinazoline derivatives. Curr Pharma Res. 2011; 1: 101-05.

Maskey RP, Shaaban M, Grün-Wollny I, Laatsch H. Quinazolin -4-one derivatives from Streptomyces isolates. J Nat Prod. 2004; 67: 1131-34.

Mathew B, Ross L, Reynolds RC. A novel quinoline derivative that inhibits mycobacterial FtsZ. Tuberculosis 2013; 93: 398400 .

Maurya HK, Verma R, Alam S, Pandey S, Pathak V, Sharma S, Srivastava KK, Negi AS, Gupta A. Studies on substituted benzo[h]quinazolines, benzo[g]indazoles, pyrazoles, 2,6diaryl pyridines as anti-tubercular agents. Bioorg Med Chem Lett. 2013; 23: 5844-49.

McLaughlin NP, Evans P, Pines M. The chemistry and biology of febrifugine and halofuginone. Bioorg Med Chem. 2014; 2: 1993-2004.

Mendoza-Martínez C, Galindo-Sevilla N, Correa-Basurto J, Ugalde-Saldivar VM, Rodríguez-Delgado RG, HernándezPineda J, Padierna-Mota C, Flores-Alamo M, HernándezLuis F. Antileishmanial activity of quinazoline derivatives: Synthesis, docking screens, molecular dynamic simulations and electrochemical studies. Eur J Med Chem. 2015; 92: 31431.

Mhaske SB, Argade NP. The chemistry of recently isolated naturally occurring quinazolinone alkaloids. Tetrahedron 2006; 62: 9787-826.

Minkovsky N, Berezov A. BIBW-2992, a dual receptor tyrosine kinase inhibitor for the treatment of solid tumors. Curr Opin Invest Drug. 2008; 9: 1336-46.

Miolo G, Salvador A, Mazzoli A, Spalletti A, Marzaro G, Chilin A. Photochemical and photobiological studies on furoquinazolines as new psoralen analogs. J Photochem Photobiol B Biol. 2014; 138: 43-54.

Modh RP, De Clercq E, Pannecouque C, Chikhalia KH Design, synthesis, antimicrobial activity and anti-HIV activity evaluation of novel hybrid quinazoline-triazine derivatives. J Enzyme Inhib Med Chem. 2014; 29: 100-08.

Mohamed HA, Lake BR, Laing T, Phillips RM, Willans CE. Synthesis and anti-cancer activity of silver(I)-N-heterocyclic carbene complexes derived from the natural xanthine products caffeine, theophylline and theobromine. Dalton Trans. 2015; 44: 7563-69.

Mohamed MA, Ghanem HM, Abd El-Ghaffar NF, Mohamed SS. Biological evaluation and molecular docking of substituted quinazolinones as antimicrobial agents. Aust J Basic Appl Sci. 2013; 7: 263-74.

Mohamed YA, Amr AEE, Mohamed SF, Abdalla MM, Al- 
Omar MA, Shfik SH. Cytotoxicity and anti-HIV evaluations of some new synthesized quinazoline and thioxopyrimidine derivatives using 4-(thiophen-2-yl)-3,4,5,6-tetrahydrobenzo [h]quinazoline-2(1H)-thione as synthon. J Chem Sci. 2012; 124: 693-702.

Murgan V, Thomas CC, Rama B, Sarma GVS, Kumar EP. Synthesis of 2-substituted quinazolin-4(3H)-ones as a new class of anti-cancer agents. Indian J Pharm Sci. 2003; 65: 38689.

Nayyar AP, Arpanarana M. An updated review: Newer quinazoline derivatives under clinical trial. Int J Pharm Biol Arch. 2011; 2: 1651-57.

Olliaro P, Wells TN. The global portfolio of new antimalarial medicines under development. Clin Pharmacol Ther. 2009; 85: 584-95.

Omori K, Kotera J. Overview of PDEs and their regulation. Circ Res. 2007; 100: 309-27.

Ouahrouch A, Taourirte M, Engels JW, Benjelloun S, Lazre HB. Synthesis of new 1,2,3-triazol-4-yl-quinazoline nucleoside and acyclonucleoside analogues. Molecules 2014; 19: 3638-53.

Palop JA, Plano D, Moreno E, Sanmartín C. Novel quinazoline and pyrido[2,3-d]pyrimidine derivatives and their hydroselenite salts as antitumoral agents. Arkivoc 2013; ii: 187-206.

Patel NB, Patel JC. Synthesis and antimicrobial activity of Schiff bases and 2-azetidinones derived from quinazolin-4 (3H)-one. Arabian J Chem. 2011; 4: 403-11.

Pathak SR, Malhotra V, Nath R, Shanker K. Synthesis and antihypertensive activity of novel quinazolin-4(3H)-one derivatives. Cent Nerv Syst Agents Med Chem. 2014; 14: 3438.

Pathania D, Sechi M, Palomba M, Sanna V, Berrettini F, Sias A, Taheri L, Neamati N. Design and discovery of novel quinazolinedione-based redox modulators as therapies for pancreatic cancer. Biochim Biophys Acta. 2014; 1840: 332-43.

Pickup M, Novitskiy S, Moses HL. The role of TGF $\beta$ in the tumour microenvironment. Nat Rev Cancer. 2013; 13: 788-99.

Popkin, BM, Adair LS, Ng SW. Global nutrition transition and the pandemic of obesity in developing countries. Nutr Rev. 2012; 70: 3-21.

Portela-Cubillo F, Scott JS, Walton JC. Microwave-promoted syntheses of quinazolines and dihydroquinazolines from 2aminoarylalkanone o-phenyl oxime. J Org Chem. 2009; 74: 4934-42.

Radnai B, Antus C, Racz B, Engelmann P, Priber JK, et al., Protective effect of the poly (ADP-ribose) polymerase inhibitor PJ34 on mitochondrial depolarization-mediated cell death in hepatocellular carcinoma cells involves attenuation of c-Jun N-terminal kinase-2 and protein kinase B/Akt activation. Mol Cancer. 2012; 11: 34-45.

Raghav N, Singh M. Design, synthesis and docking studies of bischalcones based quinazoline-2(1H)-ones and quinazoline2(1H)-thiones derivatives as novel inhibitors of cathepsin B and cathepsin H. Eur J Pharm Sci. 2014; 54: 28-39.

Rajput R, Mishra AP. A review on biological activity of quinazolinones. Int J Pharm Pharm Sci. 2012; 4: 66-70.
Redondo M, Zarruk JG, Ceballos P, Pérez DI, Pérez C, PerezCastillo A, Moro MA, Brea J, Val C, Cadavid MI, Loza MI, Campillo NE, Martínez A, Gil C. Neuroprotective efficacy of quinazoline type phosphodiesterase 7 inhibitors in cellular cultures and experimental stroke model. Eur J Med Chem. 2012; 47: 175-85.

Rojas-Aguirre Y, Hernández-Luis F, Mendoza-Martínez C, Sotomayor CP, Aguilar LF, Villena, F, Castillo I, Hernández DJ, Suwalsky M. Effects of an antimalarial quinazoline derivative on human erythrocytes and on cell membrane molecular models. Biochim Biophys Acta. 2012; 1818: 738-46.

Ryu CK, Kim YH, Im HA, Kim JY, Yoon JH, Kim A. Synthesis and antifungal activity of 6,7-bis(arylthio)-quinazoline-5,8diones and furo[2,3-f]quinazolin-5-ols. Bioorg Med Chem Lett. 2012; 22: 500-03.

Sasmal S, Balaji G, Kanna RHR, Balasubrahmanyam D, Srinivas G, Kyasa S, Sasmal PK, Khanna I, Talwar R, Suresh J, Jadhav VP, Muzeeb S, Shashikumar D, Harinder RK, Sebastian VJ, Frimurer TM, Rist $\varnothing$, Elster L, Högberg T. Design and optimization of quinazoline derivatives as melanin concentrating hormone receptor 1 (MCHR1) antagonists. Bioorg Med Chem Lett. 2012; 22: 3157-62.

Sánchez AI, Martínez-Barrasa V, Burgos C, Vaquero JJ, Alvarez-Builla J, Terricabras E, Segarra V. Synthesis and evaluation of quinazoline derivatives as phosphodiesterase 7 inhibitors. Bioorg Med Chem. 2013; 21: 2370-78.

Sangshetti JN, Khan FAK, Kulkarni AA, Aroteb R, Patil RH. Antileishmanial drug discovery: Comprehensive review of the last 10 years. RSC Adv. 2015; 5: 32376-415.

Selvam P, Sridharan D, Murugesh N, Chandramohan M, Witurouw M. Synthesis and anti-HIV activity of some novel 2,3-disubstituted quinazolin-4(3H)-ones. Int J Chem Sci. 2008; 6: 1196-201.

Selvam TP, Kumar PV. Quinazoline marketed drugs-a review. Res Pharm. 2011; 1: 1-21.

Sergey I, Igor F, Vadim V, Oksana V. Synthesis of 2-(3,4dihydro-3-oxo-2H-[1,2,4] triazino[4,3-c]quinazolin-4-yl)acetic acid derivatives as potential anti-oxidants in nitrosative stress model. Farmacia 2010; 58: 145-57.

Serya RAT, Abbas AH, Ismail NSM, Esmat A, El Ella DAA. Design, synthesis and biological evaluation of novel quinazoline-based anti-inflammatory agents acting as PDE4B inhibitors. Chem Pharm Bull. 2015; 63: 102-16.

Sharma A, Luxami V, Paul K. Synthesis, single crystal and antitumor activities of benzimidazole-quinazoline hybrids. Bioorg Med Chem Lett. 2013a; 23: 3288-94.

Sharma A, Luxami V, Saxena S, Paul K. Benzimidazole-based quinazolines: In vitro evaluation, quantitative structureactivity relationship, and molecular modeling as aurora kinase inhibitors. Arch Pharm. 2016; 349: 193-201.

Špulák M, Pourová J, Vopršálová M, Mikušek J, Kuneš J, Vacek J, Ghavre M, Gathergood N, Pour M. Novel bronchodilatory quinazolines and quinoxalines: Synthesis and biological evaluation. Eur J Med Chem. 2014; 74: 65-72.

Srivastav MK, Shantakumar SM. Design and synthesis of novel 2-trichloromethyl-4-substituted quinazoline derivatives as anti-tubercular agents. Chem Sci Trans. 2013; 2: 1056-62. 
Susín C, Morales-Garcia JA, Aguilar-Morante D, Palomo V, Sanz-Sancristobal M, Alonso-Gil S, Gil C, Santos A, Martinez A, Perez-Castillo A. The new iminothiadiazole derivative VP1.14 ameliorates hippocampal damage after an excitotoxic injury. J Neurochem. 2012; 122: 1193-202.

Takase Y, Saeki T, Watanabe N, Saito I. Cyclic GMP phosphodiesterase inhibitors. 2. Requirement of 6-substitution of quinazoline derivatives for potent and selective inhibitory activity. J Med Chem. 1994; 37: 2106-11.

Tan F, Shen X, Wang D, Xie G, Zhang X, Ding L, Hu Y, He W, Wang Y, Wang Y. Icotinib (BPI-2009H), a novel EGFR tyrosine kinase inhibitor, displays potent efficacy in preclinical studies. Lung Cancer. 2012; 76: 177-82.

Tang L, Zhou P, Zhong K, Hou S. Fluorescence relay enhancement sequential recognition of $\mathrm{Cu}^{2+}$ and $\mathrm{CN}^{-}$by a new quinazoline derivative. Sensor Actuator. B. 2013; 182: 439-45.

Tinker AC, Beaton HG, Smith NB, Cook TR, Cooper SL, Rae LF, Hallam K, Hamley P, McInally T, Nicholls DJ, Pimm AD, Wallace AV. 1,2-dihydro-4-quinazolinamines: Potent, highly selective inhibitors of inducible nitric oxide synthase which show anti-inflammatory activity in vivo. J Med Chem. 2003; 46: 913-16.

Tiumana TS, Santos AO, Ueda-Nakamuraa T, Dias Filhoa BP, Nakamuraa CV. Recent advances in leishmaniasis treatment. Int J Infect Dis. 2011; 15: e525-32.

Vagdevi HM, Lokesh MR, Gowdarshivannanavar BC. Synthesis and anti-oxidant activity of 3-substituted schiff bases of quinazoline-2,4-diones. Int J Chem Tech Res. 2012; 4: 152733.

Vijayakumar K, Ahamed AJ, Thiruneelakandan G. Synthesis, antimicrobial, and anti-HIV1 activity of quinazoline-4(3H)one derivatives. J Appl Chem. 2013: 5.

Wan Z, Hu D, Li P, Xie D, Gan X. Synthesis, antiviral bioactivity of novel 4-thioquinazoline derivatives containing chalcone moiety. Molecules 2015; 20: 11861-74.

Wang C, Sun Y, Zhu X, Wu B, Wang Q, Zhen Y, Shu X, Liu K, Zhou $Y$, Ma X. Novel quinazoline bearing various 4-aniline moieties as potent EGFR inhibitors with enhanced activity against NSCLC cell line. Cell Biol Drug Des. 2016; 87: 635-43.

Wang D, Gao F. Quinazoline derivatives: Synthesis and bioactivities. Chem Central J. 2013; 7: 95-115.

Wang X, Li ZN, Yin J, He M, Xue W, Chen ZW, Song BA. Synthesis and bioactivity evaluation of novel arylimines containing 3-aminoethyl-2-[( $p$-trifluoromethoxy)anilino]-4 (3H)-quinazolinone moiety. J Agric Food Chem. 2013; 61:
9575-958.

Wang X, Yin J, Shi L, Zhang G, Song B. Design, synthesis, and antibacterial activity of novel Schiff base derivatives of quinazolin-4(3H)-one. Eur J Med Chem. 2014; 77: 65-74.

Werbel LM, Degnan MJ. Synthesis and antimalarial and antitumor effects of 2-amino-4-(hydrazino and hydroxyamino)-6-[(aryl)thio]quinazolines. J Med Chem. 1987; 30: 2151-54.

WHO, World Health Organization. Control of the Leishmaniases. WHO Technical Report Series. Retrieved online on February 7, 2016 at http://www.who.int/leishmaniasis/ resources/en.

WHO, World Health Organization. HIV/AIDS, Fact Sheet n. 360, Updated Nov. 2015. Retrieved online on Dec. 7, 2015 at http://www.who.int/mediacentre/factsheets/fs360/en/

Williams $\mathrm{CH}$, Hong CC. Making models work: Library annotation through phenoclustering. Drug Discov Today Dis Model. 2013; 10: e5-e9.

Yassen ASA, Elshihawy HEAEA, Said MMA, Abouzid KAM. Molecular modelling and synthesis of quinazoline-based compounds as potential anti-proliferative agents. Chem Pharm Bull. 2014; 62: 454-66.

Yu H, Li Y, Ge Y, Song Z, Wang C., Huang S, Jin Y, Han X, Zhen Y, Liu K, Zhou Y, Ma X. Novel 4-anilinoquinazoline derivatives featuring an 1-adamantyl moiety as potent EGFR inhibitors with enhanced activity against NSCLC cell lines. Eur J Med Chem. 2016; 110: 195-203.

Yves LJ. Antituberculosis drugs: Ten years of research. Bioorg Med Chem. 2007; 15: 2479-513.

Zayed MF. New fluorinated quinazolinone derivatives as anticonvulsant agents. J Taibah Univ Med Sci. 2014; 9: 10409.

Zhang J, Liu J, Ma Y, Ren D, Cheng P, Zhao J, Zhang F, Yao Y. One-pot synthesis and antifungal activity against plant pathogens of quinazolinone derivatives containing an amide moiety. Bioorg Med Chem Lett. 2016; 26: 2273-77.

Zhang X, Peng T, Ji X, Li J, Tong L, Li Z, Yang W, Xu Y, Li M, Ding J, Jiang $\mathrm{H}$, Xie H, Liu H. Design, synthesis and biological evaluation of novel 4-anilinoquinazolines with C-6 urea-linked side chains as inhibitors of the epidermal growth factor receptor. Bioorg Med Chem. 2013a; 21: 7988-98.

Zhang X, Su S, Chen Y, Li J, Lu W. The design and synthesis of a new class of RTK/ HDAC dual-targeted inhibitors. Molecules 2013b; 18: 6491-503.

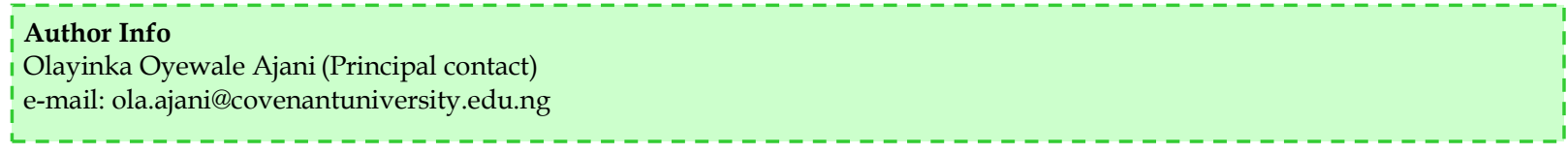




\section{Your feedback about this paper}

1. Number of times you have read this paper 0

2. Quality of paper Click

3. Your comments

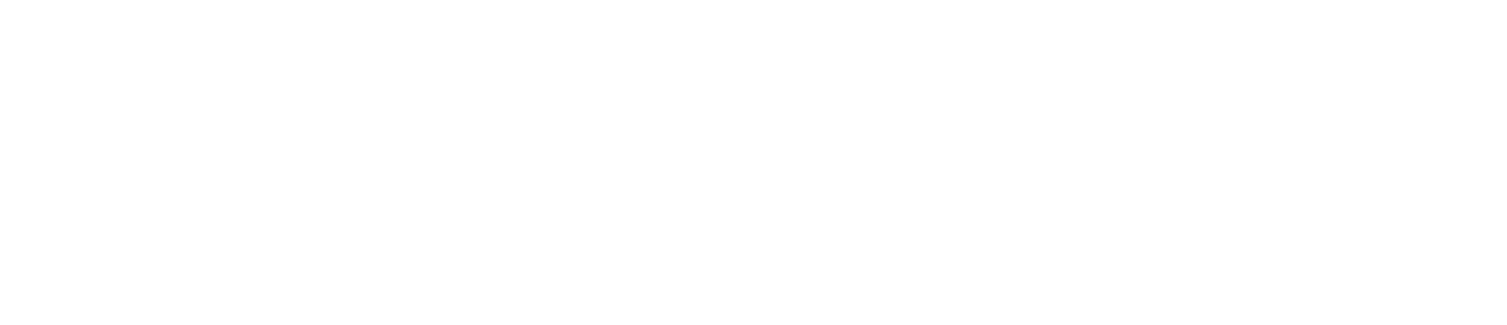

